U. S. GEOLOGICAL SURVEY WATER RESOURCES DIVISION Honolulu, Hawaii

POTENTIAL EFFECTS OF THE HAYWAII GEOTHERMAL

PROJECT ON GROUND-WATER RESOURCES

ON THE ISLAND OF HAWAII

U.S. GEOLOGICAL SURVEY

Water Resources Investigations Report 94-4028

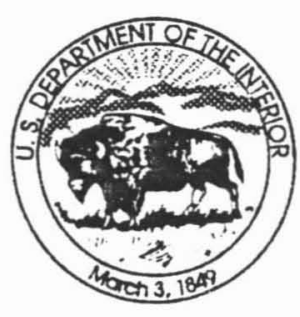

Prepared in cooperation with the U.S. DEPARTMENT OF ENERGY

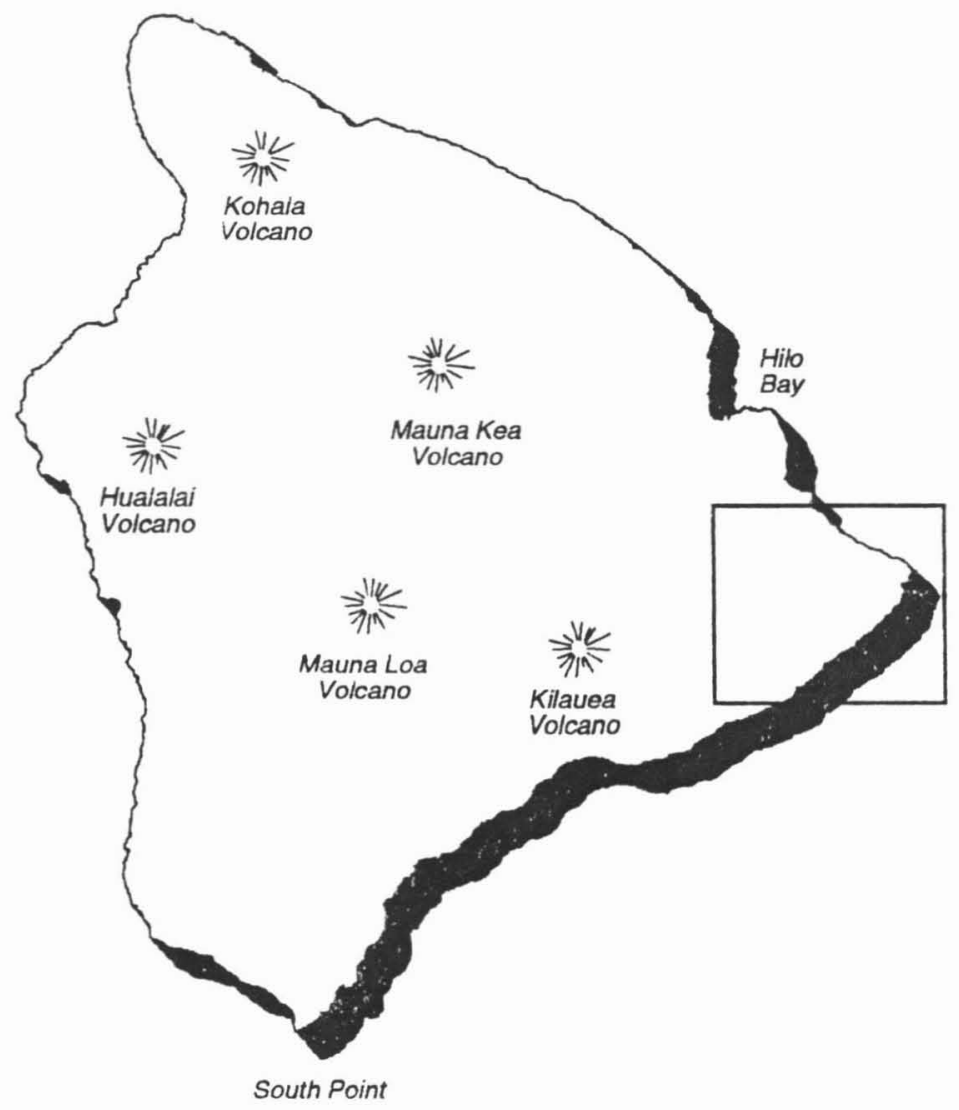


POTENTIAL EFFECTS OF THE HAWAII GEOTHERMAL

PROJECT ON GROUND-WATER RESOURCES

ON THE ISLAND OF HAWAII

Michael L. Sorey and Elizabeth M. Colvard

U.S. GEOLOGICAL SURVEY

Water Resources Investigations Report 94-4028

Prepared in cooperation with the

U.S. DEPARTMENT OF ENERGY

Menlo Park, California 


\section{U.S. DEPARTMENT OF THE INTERIOR \\ BRUCE BABBITT, Secretary \\ U.S. GEOLOGICAL SURVEY \\ Gordon P. Eaton, Director}

For additional information

write to:

Chief, Branch of Regional Research U.S. Geological Survey 345 Middlefield Road

Menlo Park, California 94025
Copies of this report can

be purchased from:

U.S. Geological Survey

Earth Science Information Center

Open-File Reports Services

Box 25286, MS 517

Federal Center

Denver, Colorado 80225-0046 


\section{CONTENTS}

Page

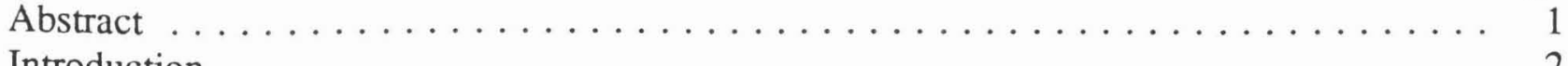

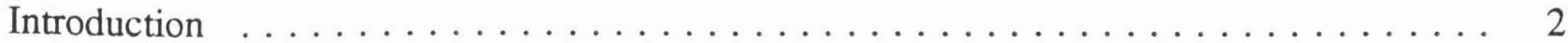

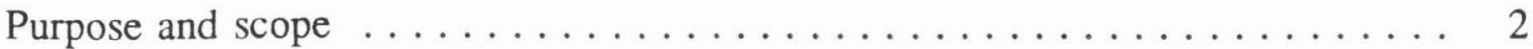

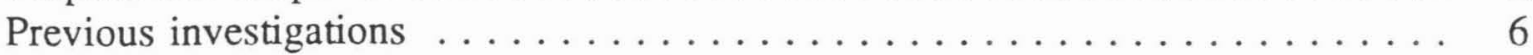

Description of ground-water systems in the study area $\ldots \ldots \ldots \ldots \ldots$

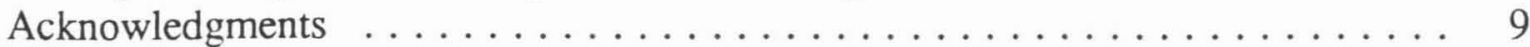

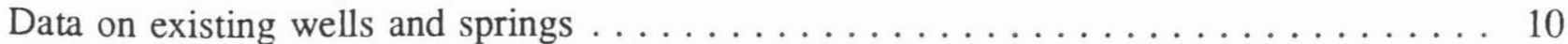

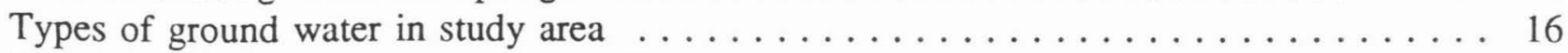

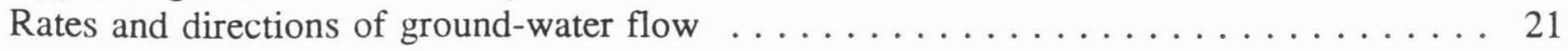

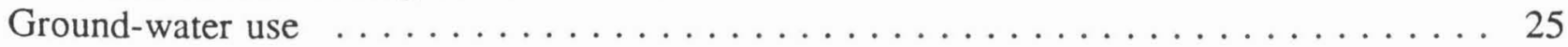

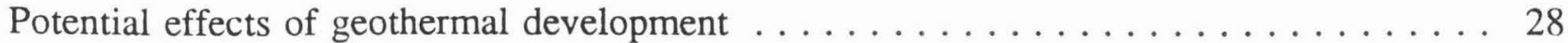

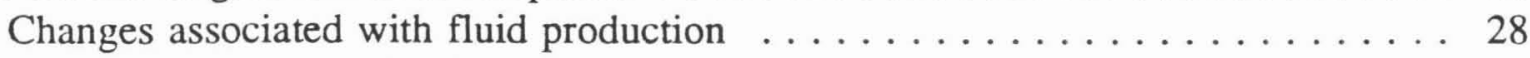

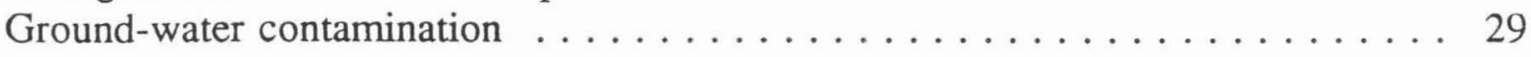

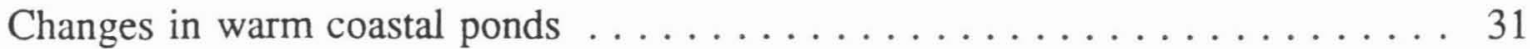

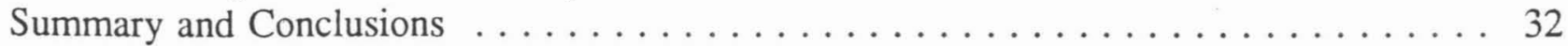

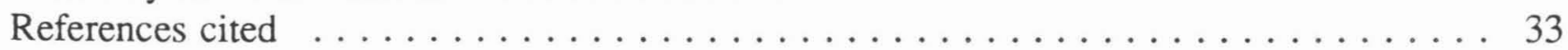




\section{ILLUSTRATIONS}

Figure 1. Map of the southern part of the Island of Hawaii showing volcanic rocks of Kilauea Volcano, rift zone axes, and locations of geothermal

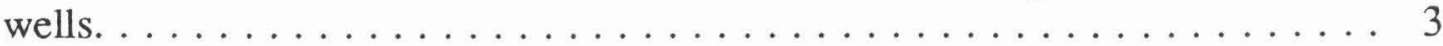

Figure 2A. Map of the lower east rift zone of Kilauea showing locations of wells (identified by name), thermal springs, and areas of hot water discharge

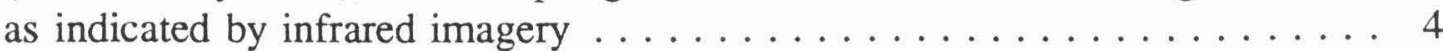

Figure 2B. Map of the lower east rift zone of Kilauea showing locations of wells (identified by state well number), thermal springs, and areas of hot water discharge as indicated by infrared imagery . . . . . . . . . . 5

Figure 3. Map of the Island of Hawaii showing general distribution of groundwater types and boundaries of major drainage basins . . . . . . . . 7

Figure 4. Map of the southern part of the Island of Hawaii showing contours of land-surface elevation and locations of wells and sampled springs . . . . . . . 8

Figure 5. Map of the lower east rift zone of Kilauea showing location of wells tapping different types of shallow ground water $\ldots \ldots \ldots \ldots \ldots$

Figure 6. Map of the lower east rift zone showing contours of water-level elevation and representative water levels measured in wells tapping basal ground water. . . . . . . . . . . . . . . . . 22

\section{TABLES}

Table 1. Inventory of wells in the study area for which data on the groundwater system are available . . . . . . . . . . . . . . . . 11

Table 2. Chloride concentrations and ionic ratios for samples from wells, warm pools, and sea water . . . . . . . . . . . . . . . . . . 13

Table 3. Monthly average pumping rates for ground-water wells in the study area . . . . . . . . . . . . . . . . . . . . . . . . . . . . 26 


\section{CONVERSION FACTORS, DEFINITION OF TERMS, AND ABBREVIATIONS}

Multiply

pounds per square inch (psi)

inch (in)

foot (ft)

mile (mi)

gallon (gal)

million gallons per day $(\mathrm{Mgal} / \mathrm{d})$

gallons per minute $(\mathrm{gal} / \mathrm{min})$

feet per day $(\mathrm{ft} / \mathrm{d})$
$\underline{B y}$

68965.517

25.4

0.3048

1.609

3.785

18.30164

0.06308

0.3670
To obtain

bar

millimeter $(\mathrm{mm})$

meter $(\mathrm{m})$

kilometer $(\mathrm{km})$

liter (L)

liter per second $(\mathrm{L} / \mathrm{s})$

liter per second $(\mathrm{L} / \mathrm{s})$

darcy (for water at $20^{\circ} \mathrm{C}$ )

Other abbreviations used:

$\mathrm{ft} / \mathrm{mi}$ - feet per mile

$\mathrm{ft} / \mathrm{yr}$ - feet per year

$\mathrm{mg} / \mathrm{L}$ - milligrams per liter

MW - Megawatt

Temperature is given in degrees Celsius $\left({ }^{\circ} \mathrm{C}\right)$, which can be converted to degrees Fahrenheit $\left({ }^{\circ} \mathrm{F}\right)$ by the following equation:

$$
\text { Temp. }{ }^{\circ} \mathrm{F}=1.8\left(\text { temp. }{ }^{\circ} \mathrm{C}\right)+32
$$

Definition of terms used:

Aquifer - a permeable formation that stores and transmits ground water in sufficient quantity to supply wells.

Anchialine pond - location along coastline where the ground-water table is exposed at the land surface in porous lavas. These pools have no surface connection to the sea.

Basal water - a freshwater lens floating on saltwater.

Brackish (water) - water with salinity greater than that of fresh water and less than that of sea water.

Brine - water with an unusually high concentration of salts.

Darcy velocity - rate of flow of water per unit cross-sectional area.

Evapotranspiration - a combination of evaporation from open bodies of water, evaporation from soil surfaces, and transpiration from the soil by plants.

Hydraulic conductivity $(\mathrm{K})$ - measure of the rate of flow of water per unit cross-sectional area under a hydraulic gradient of 1 .

(Hydraulic) head - height of water column in a well, above an arbitrary datum.

Intrinsic permeability (k) - measure of the ability of a rock formation to transmit water, related to hydraulic conductivity $(\mathrm{K})$ by the formula: $\mathrm{K}=\mathrm{k} \rho \mathrm{g} / \mathrm{\mu}$, where $\rho$ is fluid density, $\mathrm{g}$ is gravitational acceleration, and $\mu$ is fluid dynamic viscosity.

Impounded water - ground water in compartments that form within a dike intrusion complex when water movement is slowed or stopped by dike rocks of low permeability.

Littoral - the marine environment between the limits of high tide and low tide. 
Perched water - ground water that accumulates above ash layers or other low-permeability volcanic material of limited areal extent located within the lava between the water table and the land surface.

(Geothermal) reservoir - a permeable formation that stores and transmits thermal water in sufficient quantity to supply geothermal wells

Saline - possessing more than 3,000 parts per million total dissolved solids.

Transmissivity - a measure of the volumetric flow rate of ground water per unit width of reservoir for a unit hydraulic gradient. It is equal to reservoir hydraulic conductivity times reservoir saturated thickness.

Unconfined - open to the atmosphere so that water drains from the pore space as water level is lowered.

Vapor-static pressure - a column of steam whose pressure is controlled by the density of steam.

\section{ABBREVIATIONS USED IN THIS REPORT}

DBED

DLNR

DOE

DWS

EIS

ERZ

TH( 1,2$)$

HGP

HSCA

$\mathrm{KS}(1,2)$

LERZ

MERZ

$\mathrm{MW}(1,2)$

PGV

$\mathrm{SOH}(-1,2)$

TRUE

UERZ

UH

USGS
State of Hawaii Department of Business and Economic Development State of Hawaii Department of Land and Natural Resources

U.S. Department of Energy

Hawaii County Department of Water Supply

Environmental Impact Statement

East Rift Zone of Kilauea Volcano

Test Hole

Hawaii Geothermal Project

Hawaiian Shores Community Association

Kapoho State

Lower East Rift Zone of Kilauea

Middle East Rift Zone of Kilauea

Monitor Well

Puna Geothermal Venture

Scientific Observation Hole

True Mid-Pacific

Upper East Rift Zone of Kilauea

University of Hawaii

U.S. Geological Survey 


\title{
POTENTIAL EFFECTS OF THE HAWAII GEOTHERMAL PROJECT ON GROUND-WATER RESOURCES ON THE ISLAND OF HAWAII
}

\author{
Michael L. Sorey and Elizabeth M. Colvard
}

\begin{abstract}
This report provides data and information on the quantity and quality of ground-water resources in and adjacent to proposed geothermal development areas on the Island of Hawaii. In a 1990 proposal to Congress, the State of Hawaii proposed the Hawaii Geothermal Project for the development of as much as $500 \mathrm{MW}$ of electric power from the geothermal system in the East Rift Zone of Kilauea Volcano. Data presented for about 31 wells and 8 springs describe the chemical, thermal, and hydraulic properties of the ground-water system in and adjacent to the East Rift Zone. On the basis of this information, potential effects of this geothermal development on drawdown of ground-water levels and contamination of ground-water resources are discussed. Significant differences in ground-water levels and in the salinity and temperature of ground water within the study area appear to be related to mixing of waters from different sources and varying degrees of ground-water impoundment by volcanic dikes. Near Pahoa and to the east, the ground-water system within the rift is highly transmissive and receives abundant recharge from precipitation; therefore, the relatively modest requirements for fresh water to support geothermal development in that part of the east rift zone would result in minimal effects on ground-water levels in and adjacent to the rift. To the southwest of Pahoa, dike impoundment reduces the transmissivity of the ground-water system to such an extent that wells might not be capable of supplying fresh water at rates sufficient to support geothermal operations. Water would have to be transported to such developments from supply systems located outside the rift or farther downrift. Contamination of ground-water resources from accidental release of geothermal fluids into shallow aquifers could result from casing leaks in the geothermal wells and accidiental well blowouts. Subsequent contaminant migration could be rapid because of relatively high groundwater velocities in parts of the region. Hydrologic monitoring of observation wells needs to be continued throughout development of geothermal resources for the Hawaii Geothermal Project to enable the early detection of leakage and migration of geothermal fluids within the groundwater system.
\end{abstract}




\section{INTRODUCTION}

The Hawaii Geothermal Project (HGP), as proposed by the State of Hawaii in its 1990 report to Congress (State of Hawaii DBED, 1990), envisions the production of about $500 \mathrm{MW}$ of electricity from development of the geothermal resource within the East Rift Zone of Kilauea Volcano on the Island of Hawaii (fig. 1). Drilling information (Olson and Deymonaz, 1991, 1992) demonstrates the existence of permeable zones with temperatures as high as $360^{\circ} \mathrm{C}$ within the easternmost part of this zone, referred to here as the Lower East Rift Zone (LERZ). The U.S. Department of Energy (DOE) is preparing an Environmental Impact Statement (EIS) to evaluate the effects of the proposed HGP.

The existing geothermal development by Puna Geothermal Venture (PGV) is limited to a region of about $1 \mathrm{mi}^{2}$ southeast of Pahoa (figs. 2A and 2B). PGV currently has a total of $16 \mathrm{mi}^{2}$ under lease for geothermal development. The PGV powerplant consists of steam-driven turbinegenerating units and a binary cycle turbine, both of which are air-cooled (Clark and Stewart, 1991). The design capacity of the existing powerplant, which went on line in May 1993, is 25 MW. Although the PGV Plan of Operations calls for as many as 30 wells to be drilled over the expected 35-year life of the project, the existing powerplant capacity can currently be achieved using only 2-3 production wells having the discharge characteristics of most recently drilled wells. For the $500 \mathrm{MW}$ HGP, it has been postulated that there is a need for a total of about 125 production wells and 30 injection wells (State of Hawaii DBED, 1990). The total development area required by the HGP is unknown, but would probably need to extend throughout the LERZ and into the MERZ, or approximately encompassing the rift section covered by our study area (figs. 2A and 2B). The existing PGV development is not part of the HGP and has been permitted separately by various state and county agencies. However, information gained during the exploration and production phases of the PGV operation provide a useful guide to conditions that might be encountered in the larger HGP.

\section{Purpose and Scope}

This report, prepared in cooperation with the DOE, provides information on the quantity and quality of ground water in and adjacent to the Hawaii Geothermal Project area and describes potential effects from geothermal development. Data on existing wells and springs in the study area, including the LERZ and adjacent regions, was obtained from (1) files provided by the State Department of Lands and Natural Resources (DLNR), the Department of Water Supply (DWS) of Hawaii County, the University of Hawaii (UH), and the U.S. Geological Survey (USGS); (2) published and unpublished reports and papers by various researchers and consulting groups; and (3) water samples collected by the USGS (Janik and others, 1994). We use these data to describe the distribution and possible origins of ground water within the study area and to indicate the quantities and rates of ground-water flow under pre-development conditions. We delineate connections between the geothermal system in the LERZ and the overlying ground-water system on the basis of non-proprietary information from the deep geothermal wells in and around the PGV lease. Finally, we assess the potential effects of the HGP on water levels and water quality within the ground-water system. These effects could come from production and injection of geothermal fluids, accidental release of geothermal fluids into the ground-water system, and 


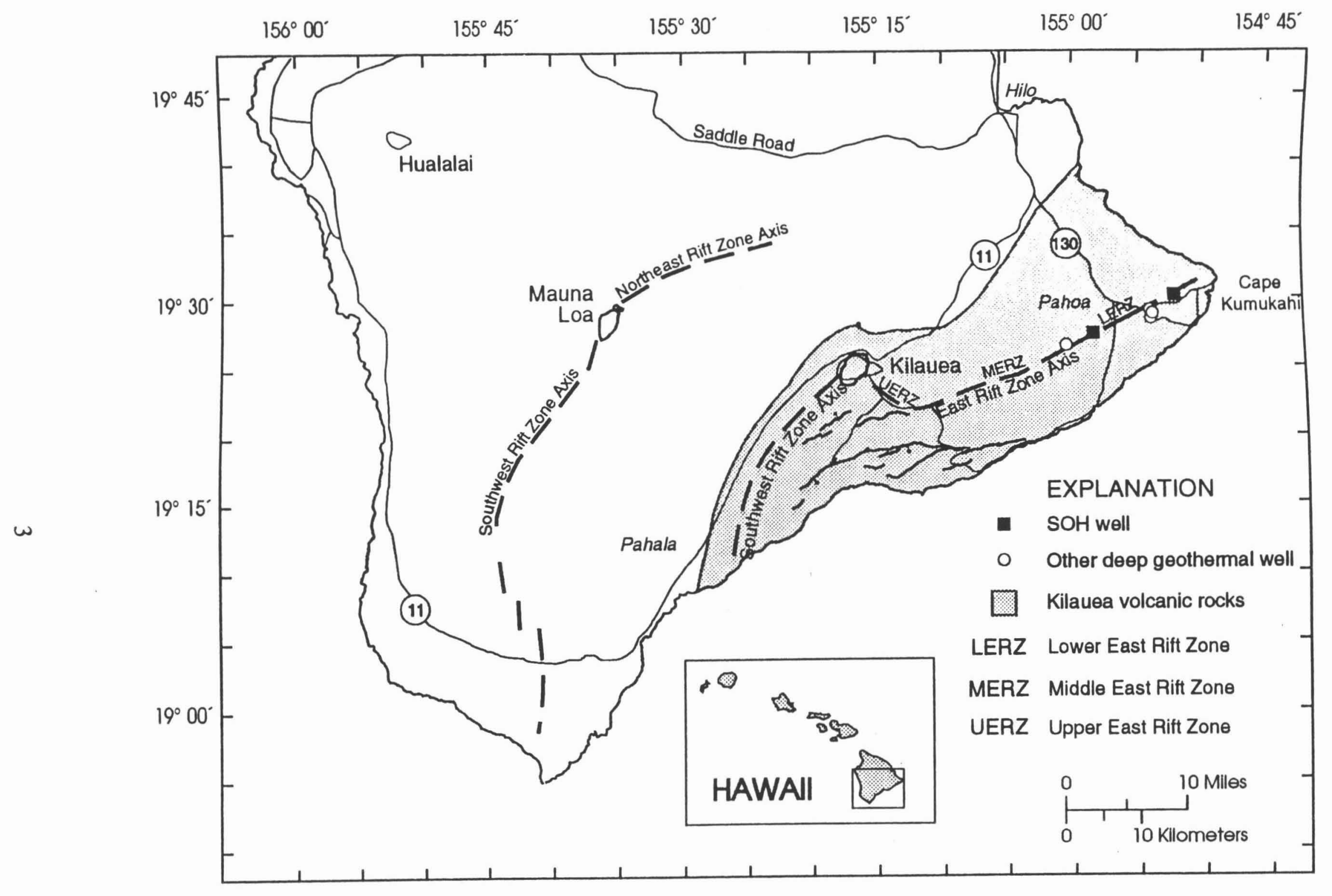

Figure 1. Map of the southern part of the Island of Hawaii showing volcanic rocks of Kilauea Volcano, axes of rift zones of Kilauea and Mauna Loa, and locations of geothermal wells. 


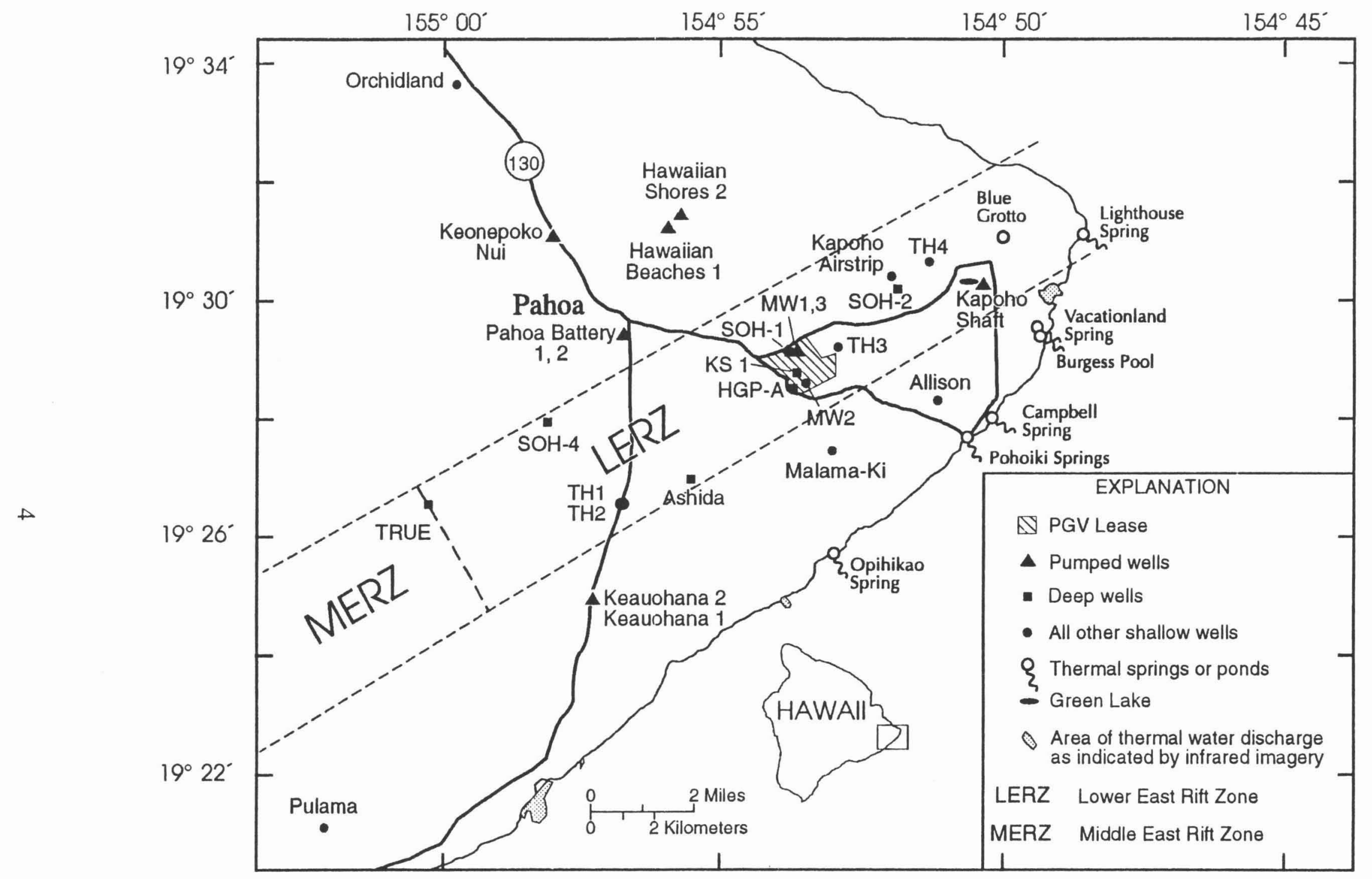

Figure 2A. Wells and springs in the study area within and adjacent to the lower east rift zone of Kilauea. Well data are listed in table 1; wells KS 1A and KS 3 (not shown) are located adjacent to KS 1. Also shown is the lease area for the existing $25 \mathrm{MW}$ geothermal development by Puna Geothermal Venture (PGV). 


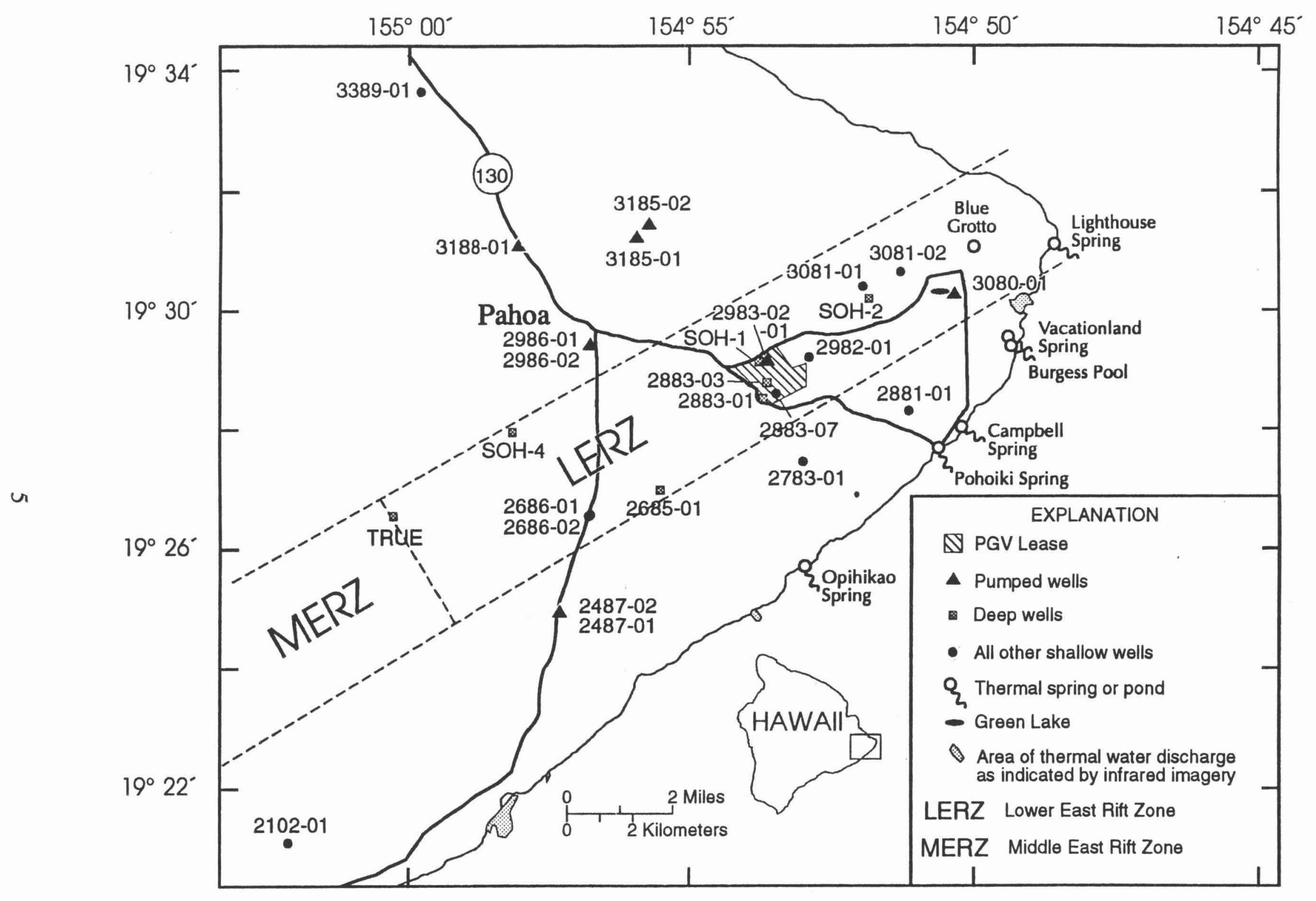

Figure 2B. Wells in the study area identified by state well number. Other features are the same as shown in figure 2A. 
pumpage of shallow ground water to support drilling, well blowout, and powerplant operations.

\section{$\underline{\text { Previous Investigations }}$}

Data from wells and springs in the vicinity of Kilauea's east rift zone (ERZ) have been presented and interpreted to varying degrees in previous studies by Stearns and Macdonald (1946), Davis and Yamanaga (1968, 1973), Druecker and Fan (1976), Imada (1984), and Takasaki (1994). A summary and synthesis of these and other hydrologic studies of the Kilauea Volcano area was presented by Ingebritsen and Scholl (1993a,b).

\section{Description of ground-water systems in the study area}

The general occurrence of ground water on the Island of Hawaii is illustrated by Takasaki (1994) as (1) basal freshwater floating on saline ground water, (2) brackish basal ground water in dike-free rocks, (3) ground water impounded by dikes in rift zones, and (4) ground water perched on soil or ash layers overlying basal ground water (fig. 3). This distribution is common to each of the five major volcanoes on the island. Under hydrostatic conditions at temperatures near $25^{\circ} \mathrm{C}$, the thickness of the fresh-water lens is determined from the Ghyben-Herzberg relation between the relative densities of salt water and fresh water and the altitude of the water table above sea level. This relation would put the base of the fresh-water lens $40 \mathrm{ft}$ below sea level for every foot the water table is above sea level. In the rift zones of Kilauea, however, geothermal heating lowers the density of the saline water and induces localized upwelling of saline water into the fresh-water lens.

The distribution of wells and springs tapping different parts of the ground-water system on Kilauea Volcano and adjacent parts of Mauna Loa Volcano is shown in figure 4. Ground water is recharged by infiltration of rainfall on the flanks of Kilauea and Mauna Loa volcanoes; ground-water discharge occurs in springs and diffuse seepage along the coast and to a lesser extent in steam vents on active volcanic features along the rift zones. Ground-water discharge along the coast occurs at temperatures both above and below ocean temperature (about $26^{\circ} \mathrm{C}$ ). Ground-water discharge as warm as about $40^{\circ} \mathrm{C}$ has been identified south of the east and southwest rift zones of Kilauea (Janik and others, 1994). Heated ground water emerges in anchialine ponds that are tidally influenced and as diffuse seepage identified by infrared surveys (Fisher and others, 1966). The likely source of this thermal water is convective circulation in or adjacent to geothermal systems in the rift zones.

With the exception of the parts of the rift zones pervasively intruded by dikes, the Kilauea lavas provide permeable aquifers for lateral ground-water flow through joints, flow contacts, and lava tubes. Druecker and Fan (1977) give an estimated average permeability for the basal ground water system of 4,000-5,000 darcies, which is equivalent to a hydraulic conductivity of 11,000 $13,500 \mathrm{ft} / \mathrm{d}$ at temperatures near $20^{\circ} \mathrm{C}$. Rates of recharge to the basal fresh-water system in and adjacent to the ERZ are high because there is little or no surface runoff and average rates of evapotranspiration (4-6 ft/yr) are less than rainfall rates (8-12 ft/yr) (Ingebritsen and Scholl, 1993b; Takasaki, 1994). 


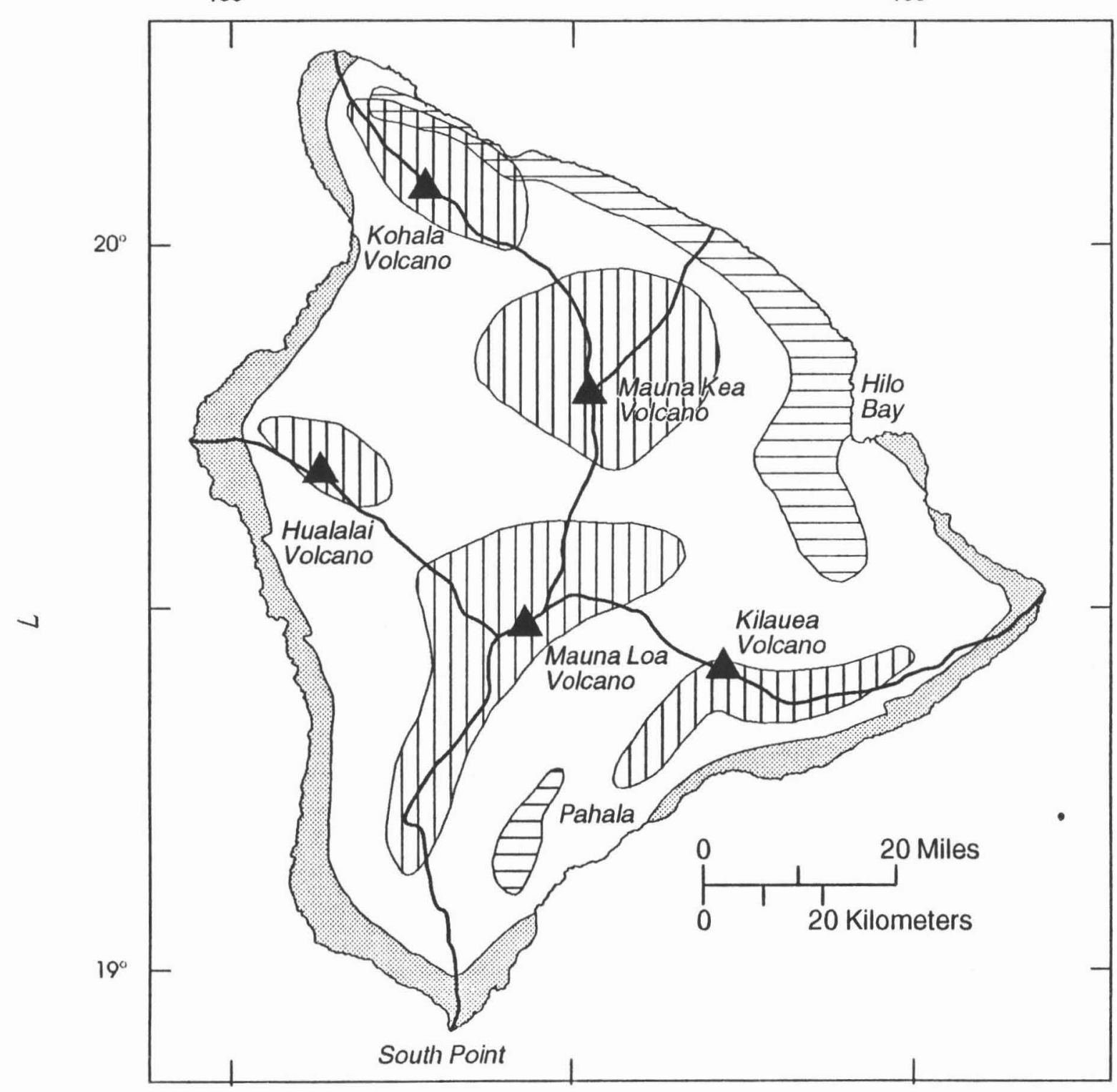

\section{EXPLANATION}

Basal ground water floating on saline ground water

Brackish basal ground water in dike-free rocks

Ground water impounded by dikes in rift zones

\section{Ground water perched on \\ soil or ash layers overlying}

basal ground water

Boundary of major drainage basin

- Volcano

Figure 3. General distribution of different ground-water types and boundaries of major drainage basins on the Island of Hawaii (From Takasaki, 1994). 


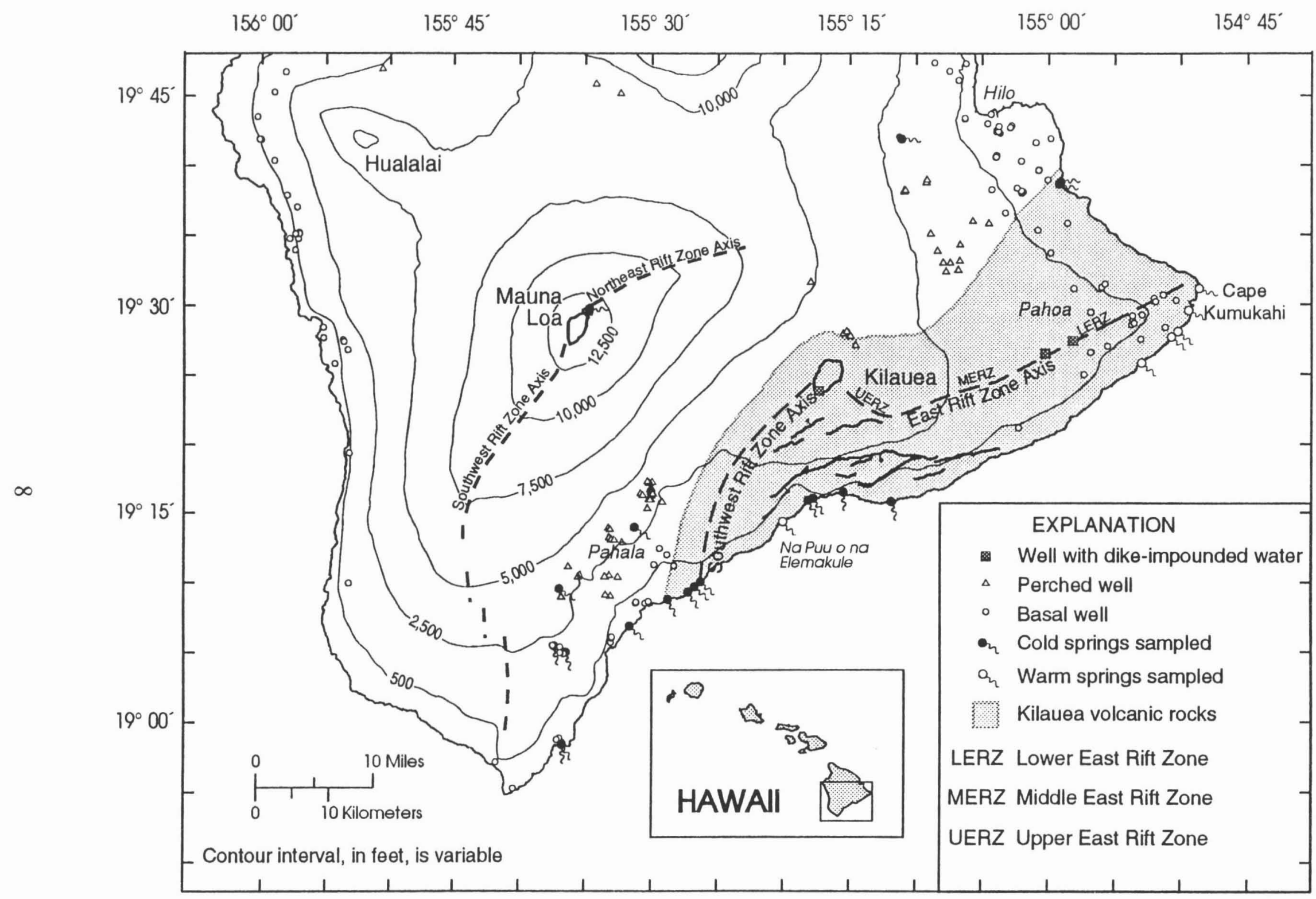

Figure 4. Map of the southern part of the Island of Hawaii showing contours of land-surface elevation, locations of existing wells, and locations of springs sampled by Janik and others (1994). 
The rift zones on Hawaiian volcanoes contain abundant dikes, commonly less than $6 \mathrm{ft}$ in width (Walker, 1987), and generally decreasing in frequency nearer the surface and farther away from the summit crater. These dikes impound water in compartments within higher permeability rock (Hunt and others, 1988). Indirect evidence of this high-level water within the Upper East Rift Zone (UERZ) and the Middle East Rift Zone (MERZ) is provided by electrical geophysical measurements (Kauahikaua, 1993). Dike-impounded ground water has been encountered near the MERZ-LERZ boundary in two geothermal exploration wells and in a well drilled at Kilauea summit. As the concentration of shallow dikes decreases downrift, water levels more closely approach sea level. Dike impoundment does not appear to have significant effects on groundwater levels east of Pahoa.

In this report, the ground-water system is considered to include fresh water and saline water at depths less than about $2,000 \mathrm{ft}$, where temperatures are generally less than about $50^{\circ} \mathrm{C}$. Temperature profiles and core mineralogy in existing wells commonly indicate nearly isothermal conditions and an absence of hydrothermal alteration within the upper 2,000 $\mathrm{ft}$ of the volcanic section (see, for example, Thomas, 1987 and Olson and Deymonaz, 1992). At greater depths, temperatures rise, the degree of hydrothermal alteration increases, and rock permeability presumably decreases. High-temperature geothermal system(s) exist at greater depths within parts of the ERZ. A degree of hydrologic connection between the ground-water system and the underlying geothermal system is indicated by the occurrence of hot, saline ground water at several locations within and south of the LERZ.

\section{Acknowledgments}

We gratefully acknowledge the assistance of several key individuals in our efforts to collect, evaluate, and interpret the available ground-water and geothermal data for the Puna area. They include James P. Kauahikaua, Cathy J. Janik, Hideo Gushiken, and Paul R. Eyre (USGS), Glenn Bauer and Johnathan Florez (DLNR), Steven Gingerich (UH), and William Sewake and Curino Antonio (DWS). 


\section{DATA ON EXISTING WELLS AND SPRINGS}

Data for the 30 wells drilled in the study area (shown in figs. $2 \mathrm{~A}$ and $2 \mathrm{~B}$ ) and a well drilled at Kilauea summit are listed in table 1. In some cases, values listed in existing data bases were not confirmed because drilling reports could not be found. In a few cases, conflicting information is given in drilling reports and reports of subsequent testing and monitoring. The well data listed in table 1 were judged to be the most reliable and/or to reflect the range of values reported in different sources.

Water levels represent altitudes of the water surface (above a sea level datum) measured in each well. A range of values is listed in instances where periodic measurements indicate variations due to ocean-tide fluctuations, recent pumping, or other, unknown, influences. For well SOH-4 (Scientific Observation Hole-4) the range of values represents depth-to-water measurements made as the hole was being drilled, as described in an unpublished drilling report (J.E. Deymonaz, drilling consultant, written commun., 1991). These measurements indicated "high level" dike-impounded ground water at that location; the highest water-level elevation (845 $\mathrm{ft}$ ) applies to drilling depths less than $2,200 \mathrm{ft}$ and the lowest water level elevation (145 $\mathrm{ft}$ ) applies to the depth interval 2,270-2,700 ft. The water-level listed for the True Mid-Pacific well was estimated from a downhole pressure survey run in April 1991, about 4 months after well completion.

Temperatures listed for the relatively shallow wells are based on measurements of pumped fluid during initial testing, or maximum values in subsequent downhole temperature surveys (Epp and Halunen, 1979). For the deep wells, both a maximum temperature encountered and a temperature representative of measurements over depths of 500-1,000 ft are given. The listed chloride concentrations for the shallow wells were obtained from samples collected during initial testing and subsequent monitoring or, where available, from samples collected in 1991 and 1992 by the U.S. Geological Survey (Janik and others, 1994). Chloride concentrations listed for the PGV geothermal wells and HGP-A are based on samples collected at the wellhead during postcompletion flow tests.

About ten deep wells have been drilled on the PGV lease. The wells, denoted Kapoho State $1-10$, are commonly referred to by the abbreviated label KS 1 through KS 10. Data for four of these wells, obtained from both shallow and deep depths, are included in table 1 . The PGV wells encountered temperatures above $250^{\circ} \mathrm{C}$ at depths of $1,500-6,000 \mathrm{ft}$; maximum temperatures are near $360^{\circ} \mathrm{C}$. A wide range of fluid types, including hot brine and hot, high-pressure steam with abundant dissolved gas, has been sampled from different wells. The PGV well data are discussed in the next section as they pertain to possible contributions of "geothermal fluids" to the shallow ground-water system in the study area, both under natural conditions and in the event of well failures that might allow these fluids to leak into the shallow system.

A comprehensive presentation of chemical data for wells and springs in the region shown in figure 4 is given by Janik and others (1994), who report data collected over the 1991-1992 period by the U.S. Geological Survey as well as analyses reported by previous investigators. In this

report, only chloride concentrations and ratios of $\mathrm{Cl} / \mathrm{Mg}, \mathrm{Cl} / \mathrm{B}$, and $\mathrm{Cl} / \mathrm{Br}$ for representative samples from our study area are presented (table 2). These characteristics are sufficient for 
lable 1. Inventory of wells in the study area for which data on the grouna-water system are avallaule

$[--$, no data]

\begin{tabular}{|c|c|c|c|c|c|c|c|c|c|c|c|c|c|c|c|c|c|}
\hline \multirow[b]{2}{*}{ Well \# } & \multirow[b]{2}{*}{ Well Name } & \multirow[b]{2}{*}{$\begin{array}{l}\text { Major } \\
\text { Use }^{2}\end{array}$} & \multirow[b]{2}{*}{ Owner/User ${ }^{3}$} & \multirow[b]{2}{*}{$\begin{array}{c}\text { Year } \\
\text { Drilled }\end{array}$} & \multicolumn{2}{|c|}{ COORDINATES } & \multicolumn{2}{|c|}{ PHYSICAL DATA } & \multicolumn{5}{|c|}{ ELEVATIONS IN FEET } & \multicolumn{2}{|c|}{$\begin{array}{l}\text { REPRESENTATIVE } \\
\text { MEASUREMENTS }\end{array}$} & \multicolumn{2}{|c|}{$\begin{array}{l}\text { PUMP TEST } \\
\text { RESULTS }\end{array}$} \\
\hline & & & & & Latitude & Longitude & $\begin{array}{l}\text { Casing } \\
\text { Inches }\end{array}$ & $\begin{array}{l}\text { Depth } \\
\text { Feet }\end{array}$ & $\begin{array}{l}\text { Ground } \\
\text { Elev }\end{array}$ & $\begin{array}{l}\text { Bottom } \\
\text { Solid }\end{array}$ & $\begin{array}{l}\text { Bottom } \\
\text { Perf }\end{array}$ & $\begin{array}{c}\text { Bottom } \\
\text { Hole }\end{array}$ & $\begin{array}{l}\text { Water } \\
\text { Level }\end{array}$ & $\begin{array}{l}\text { Temp }{ }^{7} \\
{ }^{\circ} \mathrm{C}\end{array}$ & $\begin{array}{c}\mathrm{Cl} \\
\mathrm{mg} / \mathrm{L}\end{array}$ & $\begin{array}{l}\text { Pumprate } \\
\text { gal/min }\end{array}$ & $\begin{array}{c}\text { Drawdown } \\
\mathrm{ft}\end{array}$ \\
\hline $2102-01$ & PULAMA & UNU & ABANDONED & 1963 & $19^{\circ} 21^{\prime} 07^{\prime \prime}$ & $155^{\circ} 02^{\prime} 12^{\prime \prime}$ & 8 & 250 & 230 & 0 & -20 & -20 & 3 & $26 p$ & $280-345$ & 50 & 0.4 \\
\hline $2317-01$ & KELLER (NSF) & UNU & HVNP & 1973 & $19^{\circ} 23^{\prime} 45^{\prime \prime}$ & $155^{\circ} 17^{\prime} 20^{\prime \prime}$ & 14 & 4127 & 3606 & 2581 & - & -521 & 1806 & 35 & 4 & -. & - \\
\hline $2487-01$ & KEAUOHANA 1 & MUN & HAWAII DWS & 1961 & $19^{\circ} 24^{\prime} 56^{\prime \prime}$ & $154^{\circ} 57^{\prime} 19^{\prime \prime}$ & 8 & 802 & 752 & 5 & -48 & -50 & 48 & $24-28 p$ & $70-132$ & 310 & 0.5 \\
\hline $2487-02$ & KEAUOHANA 2 & MUN & HAWAII DWS & 1970 & $19^{\circ} 24^{\prime} 57^{\prime \prime}$ & $154^{\circ} 57^{\prime} 18^{\prime \prime}$ & 12 & 803 & 752 & 9 & -51 & -51 & $2-5$ & $24 \mathrm{p}$ & $124-160$ & 500 & 16.2 \\
\hline $2600-01$ & TRUE REDRIIL 4 & GTH & TMP & 1990 & $19^{\circ} 26^{\prime} 32^{\prime \prime}$ & $155^{\circ} 00^{\prime} 19^{\prime \prime}$ & 10 & 5335 & 1503 & - & - & -- & $4(518)$ & $319(30)$ & - & - & - \\
\hline $2685-01$ & ASHIDA NO. 1 & UNU & BARNWELL GEDCO & 1980 & $19^{\circ} 26^{\prime} 59^{\prime \prime}$ & $154^{\circ} 55^{\prime} 32^{\prime \prime}$ & - & 8300 & 802 & - & - & -7498 & 17 & $326(50)$ & 8460 & - & - \\
\hline $2686-01$ & PUNA THERMAL THI & UNU & HAW THERML PWR & 1961 & $19^{\circ} 26^{\prime} 34^{\prime \prime}$ & $154^{\circ} 56^{\prime} 46^{\prime \prime}$ & 14 & 178 & 1009 & 832 &.- & 831 & dry & 54 & - & - & - \\
\hline $2686-02$ & PUNA THERMAL TH2 & UNU & HAW THERML PWR & 1961 & $19^{\circ} 26^{\prime} 33^{\prime \prime}$ & $154^{\circ} 56^{\prime} 48^{\prime \prime}$ & 14 & 556 & 1035 & 928 & - & 479 & dry & 97 & - & - & - \\
\hline $2783-01$ & MALAMA KI & UNU & STATE DOWALD & 1962 & $19^{\circ} 27^{\prime \prime} 28^{\prime \prime}$ & $154^{\circ} 53^{\prime} 01^{\prime \prime}$ & 8 & 319 & 274 & - & -45 & -45 & $1-4$ & 54 & 5530 & 480 & 0.8 \\
\hline 2788-01 & $\mathrm{SOH}-4^{1}$ & OBS & UNIV OF HAWAII & 1990 & $19^{\circ} 27^{\prime} 20^{\prime \prime}$ & $154^{\circ} 58^{\prime} 09^{\prime \prime}$ & 7 & 6562 & 1198 & -802 & -5362 & - & 's $145-845$ & $306(35)$ & - & - & - \\
\hline $2881-01$ & ALLUSON & IRR & ONELOA CO INC & 1973 & $19^{\circ} 28^{\prime} 19^{\prime \prime}$ & $154^{\circ} 51^{\prime} 10^{\prime \prime}$ & 4 & 140 & 132 & 14 & -6 & -8 & $2-5$ & 39 & $280-2040$ & 42 & - \\
\hline $2883-01$ & HGP-A & GTH & NAT ENERGY LAB & 1976 & $19^{\circ} 28^{\prime} 31^{\prime \prime}$ & $154^{\circ} 53^{\prime} 43^{\prime \prime}$ & - & 6455 & 600 & - & - & -5855 & - & $360(40)$ & ${ }^{9} 1200-7000$ & - & - \\
\hline $2883-03$ & KAPOHO STATE 1 & GTH & PGV & 1981 & $19^{\circ} 28^{\prime} 47^{\prime \prime}$ & $154^{\circ} 53^{\prime} 39^{\prime \prime}$ & 7 & 7290 & 619 & -3453 & -6671 & -6671 & 11 & $343(50)$ & $(\text { steam })^{9}$ & -- & - \\
\hline $2883-06$ & KAPOHO STATE $1 \mathrm{~A}$ & GTH & PGV & 1985 & $19^{\circ} 28^{\prime} 48^{\prime \prime}$ & $154^{\circ} 53^{\prime} 37^{\prime \prime}$ & 7 & 6505 & 620 & -3441 & - & -5885 & -. & 354 & ${ }^{9} 14,300$ & - & - \\
\hline 2883-07 & PUNA GEO MW2 & OBS & PGV & 1991 & $19^{\circ} 28^{\prime} 36^{\prime \prime}$ & $154^{\circ} 53^{\prime} 30^{\prime \prime}$ & 4 & 640 & 588 & 14 & -46 & -52 & $16-18$ & $51-63$ & $533-1060$ & - & - \\
\hline 2883-09 & KAPOHO STATE 3 & GTH & PGV & 1991 & $19^{\circ} 28^{\prime} 43^{\prime \prime}$ & $154^{\circ} 53^{\prime} 39^{\prime \prime}$ & 7 & 7406 & 613 & -3448 & - & -6793 & - & 350 & ${ }^{9}(30,000)$ & - & - \\
\hline 2883-11 & KAPOHO STATE 8 & GTH & PGV & 1991 & $19^{\circ} 28^{\prime} 48^{\prime \prime}$ & $154^{\circ} 53^{\prime} 28^{\prime \prime}$ & - & 3488 & 630 & - & - & -2858 & - & 332 & 917 & - & - \\
\hline $2982-01$ & PUNA THERMAL TH3 & UNU & HAW THERML PWR & 1961 & $19^{\circ} 29^{\prime} 13^{\prime \prime}$ & $154^{\circ} 52^{\prime} 55^{\prime \prime}$ & 18 & 690 & 563 & - & - & -127 & 5 & 93 & $2980-6042$ & - & - \\
\hline 2983-01 & KAPOHO PUNA MW1 & OTH & PGV & 1990 & $19^{\circ} 29^{\prime} 08^{\prime \prime}$ & $154^{\circ} 53^{\prime} 39^{\prime \prime}$ & 10 & 720 & 610 & -12 & -62 & -110 & 8 & $40 \mathrm{p}$ & 20 & 250 & - \\
\hline 2983-02 & KAPOHO PUNA MW3 & Отн & PGV & 1991 & $19^{\circ} 29^{\prime} 10^{\prime \prime}$ & $154^{\circ} 53^{\prime} 40^{\prime \prime}$ & 13 & 720 & 610 & -70 & - & -110 & ${ }^{6} 5-8$ & $41 \mathrm{p}$ & 18 & 1038 & 1.0 \\
\hline 2983-03 & $\mathrm{SOH}-1^{1}$ & OBS & UNIV OF HAWAII & 1991 & $19^{\circ} 29^{\prime} 07^{\prime \prime}$ & $154^{\circ} 53^{\prime} 50^{\prime \prime}$ & 7 & 5526 & 610 & -2412 & -4914 & - & $1-5$ & $206(32)$ & - & - & - \\
\hline 2986-01 & PAHOA BATTERY $2 \mathrm{~A}$ & MUN & HAWAII DWS & 1960 & $19^{\circ} 25^{\prime} 25^{\prime \prime}$ & $154^{\circ} 56^{\prime} 46^{\prime \prime}$ & 8 & 755 & 705 & 23 & -49 & -50 & $16-22$ & $22 p$ & $4-14$ & 314 & 0.5 \\
\hline $2986-02$ & PAHOA BATTERY 2B & MUN & HAWAII DWS & 1963 & $19^{\circ} 29^{\prime} 24^{\prime \prime}$ & $154^{\circ} 56^{\prime} 47^{\prime \prime}$ & - & 755 & 711 & -- & - & - & $17-23$ & 22 & 10 & - & -- \\
\hline $3080-01$ & KAPOHO SHAFT & MUN & HAWAII DWS & 1965 & $19^{\circ} 30^{\prime} 16^{\prime \prime}$ & $154^{\circ} 50^{\prime} 21^{\prime \prime}$ & 66 & 46 & 38 & -8 & - & -8 & $2-4$ & $25 p$ & $100-300$ & 382 & 4.2 \\
\hline $3081-01$ & KAPOHO AIRSTRIP & UNU & HAWAII DWS & 1961 & $19^{\circ} 30^{\prime} 24^{\prime \prime}$ & $154^{\circ} 51^{\prime} 59^{\prime \prime}$ & 8 & 337 & 287 & - & - & -50 & 3 & $35-37$ & $220-450$ & 317 & 1.0 \\
\hline $3081-02$ & PUNA THERMAL TH4 & UNU & HAW THERML PWR & 1961 & $19^{\circ} 30^{\prime} 39^{\prime \prime}$ & $154^{\circ} 51^{\prime} 19^{\prime \prime}$ & 14 & 290 & 250 & - & - & -40 & -. & $35-43$ & 72 & - & - \\
\hline $3081-03$ & SOH-2 ${ }^{1}$ & OBS & UNIV OF HAWAII & 1993 & $19^{\circ} 30^{\prime} 11^{\prime \prime}$ & $154^{\circ} 51^{\prime} 55^{\prime \prime}$ & 7 & 6802 & 400 & -3727 & -6400 & -- & - & $350(35)$ & - & - & - \\
\hline $3185-01$ & HAWAIIAN BEACHES & DOM & HSCA & 1964 & $19^{\circ} 31^{\prime} 13^{\prime \prime}$ & $154^{\circ} 55^{\prime} 58^{\prime \prime}$ & 8 & 446 & 402 & -24 & -44 & -44 & $8-11$ & $22 \mathrm{p}$ & $10-16$ & 425 & 1.7 \\
\hline $3185-02$ & HAWAIIAN SHORES & DOM & MIILER/LIEB & 1971 & $19^{\circ} 31^{\prime} 26^{\prime \prime}$ & $154^{\circ} 55^{\prime} 44^{\prime \prime}$ & 10 & 430 & 380 & -7 & - & -50 & - & - & - & 350 & 3.5 \\
\hline $3188-01$ & KEONEPOKO NUI & MUN & HAWAII DWS & 1977 & $19^{\circ} 31^{\prime} 05^{\prime \prime}$ & $154^{\circ} 58^{\prime} 03^{\prime \prime}$ & 14 & 650 & 603 & 2 & -18 & -47 & 15 & 20p & 4 & 1000 & 0.6 \\
\hline $3389-01$ & ORCHIDLAND & MUN & HAWAII DWS & 1960 & $19^{\circ} 33^{\prime} 39^{\prime \prime}$ & $154^{\circ} 59^{\prime} 49^{\prime \prime}$ & 8 & 475 & 427 & 24 & -- & -48 & $17-23$ & $23 p$ & $6-12$ & 340 & 0.9 \\
\hline
\end{tabular}

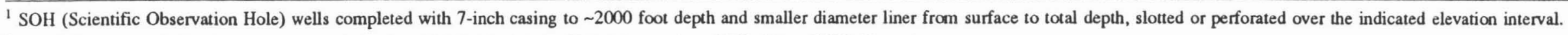

${ }^{2}$ DOM=Domestic, GTH=Geothermal, IRR=Irrigation, MUN=Municipal, OBS=Observation, OTH=Other, UNU=Unused.

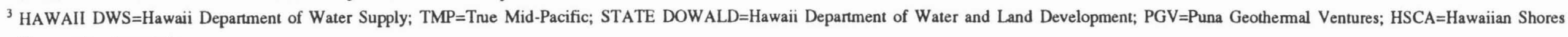
Community Association.

${ }^{4}$ Estimated from pressure survey run April 24, 1991 (approximately 5 months after completion). 


\section{Table 1.--Inventory of wells in the study area--continued}

${ }^{5}$ Range of values measured during drilling; lowest value applies to well depths of $2270-2700 \mathrm{ft}$; highest values apply to depths less than $2270 \mathrm{ft}$.

${ }^{6}$ Based on data in completion and monitoring reports, with reported depths to water reduced by $11 \mathrm{ft}$ to account for difference in air-line depth listed on form and inferred from completion diagrams.

${ }^{7}$ Maximum temperature encountered, or flowing temperature if followed by "p"; values in ( ) are representative of conditions in the depth interval $500-1000 \mathrm{ft}$.

${ }^{8} \mathrm{Cl}$ value from bailer sample from approximately $800 \mathrm{ft}$ depth, as listed in DLNR well file.

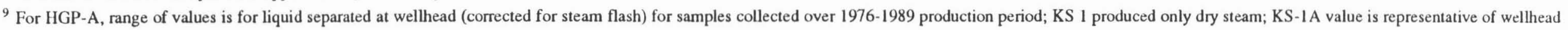

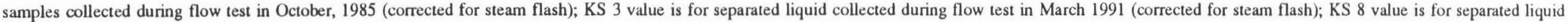
derived from steam condensate. 
Table 2. Chloride concentrations and ionic ratios for samples from wells, warm pools, and sea water in the study area.

[Samples collected by C. Janik, USGS, and analyzed by P.E. Trujillo and D. Counce, Los Alamos National Laboratory, except as noted in footnote 1; nd, not determined]

\begin{tabular}{|c|c|c|c|c|c|c|c|}
\hline Feature & Date & $\begin{array}{l}\text { Water } \\
\text { Type }^{4}\end{array}$ & $\begin{array}{l}\mathrm{T}^{5} \\
{ }^{\circ} \mathrm{C}\end{array}$ & $\begin{array}{c}\mathrm{Cl} \\
\mathrm{mg} / \mathrm{L}\end{array}$ & $\mathrm{Cl} / \mathrm{Mg}$ & $\mathrm{Cl} / \mathrm{B}^{6}$ & $\mathrm{Cl} / \mathrm{Br}$ \\
\hline Sea water & (Hem) & - & - & 19,000 & 14.1 & 4,200 & 284 \\
\hline Hawaiian Beaches & $9 / 16 / 92$ & I & 23 & 16 & 5.7 & 129 & 775 \\
\hline Keonepoko Nui & $9 / 15 / 92$ & I & 20 & 4 & 0.9 & $>175$ & $>175$ \\
\hline Orchidland & $1 / 13 / 61$ & I & 23 & 6 & nd & nd & nd \\
\hline Pahoa Battery 2A & $8 / 8 / 91$ & I & 23 & 4.3 & 1.7 & $>215$ & $>225$ \\
\hline Kapoho Shaft & $8 / 14 / 91$ & II & 25 & 128 & 3.8 & 4270 & 298 \\
\hline Keauohana 1 & $8 / 8 / 91$ & II & 24 & 54 & 22 & 2700 & 490 \\
\hline Pulama & $12 / 6 / 63$ & II & 26 & 345 & 11.1 & nd & nd \\
\hline Kapoho Puna MW1 & $9 / 16 / 92$ & III & 44 & 19.6 & 1.5 & 73 & 392 \\
\hline Kapoho Puna MW3 & $9 / 16 / 92$ & III & 44 & 19.9 & 1.5 & 71 & 498 \\
\hline Allison & $1 / 7 / 75$ & IV & 38 & 281 & 18.7 & nd & nd \\
\hline Puna Thermal TH4 & $6 / 21 / 61$ & IV & 43 & 72 & 9.6 & nd & nd \\
\hline Kapoho Airstrip & $1 / 11 / 82$ & IV & 35 & 390 & 17.4 & nd & nd \\
\hline Puna Thermal TH3 & $9 / 16 / 92$ & $\mathrm{~V}$ & 89 & 6042 & 29.5 & 2863 & 290 \\
\hline HGP-A (shallow) ${ }^{2}$ & 1976 & V & $(150)$ & 4720 & 337 & nd & nd \\
\hline Kapoho State 1 (shallow) $^{2}$ & 1985 & V & (45) & 1150 & 38 & nd & nd \\
\hline Kapoho State 1A (shallow) ${ }^{2}$ & 1985 & $\mathrm{~V}$ & $(50)$ & 1098 & 405 & nd & nd \\
\hline Kapoho Puna MW2 & $8 / 6 / 91$ & V & 58 & 533 & 27.3 & 2960 & 303 \\
\hline Kapoho Puna MW2 & $9 / 16 / 92$ & V & 57 & 1060 & 83.5 & 2360 & 328 \\
\hline Malama ki & $4 / 28 / 93$ & $\mathrm{~V}$ & 53 & 4670 & 15.6 & 2080 & 270 \\
\hline Kapoho State $1 \mathrm{~A}^{3}$ & $10 / 24 / 85$ & $\mathrm{HB}$ & 310 & 15,700 & 9130 & 2620 & 267 \\
\hline Kapoho State $3^{3}$ & $3 / 27 / 91$ & $\mathrm{HB}$ & 318 & 30,300 & 1090 & 2070 & nd \\
\hline HGP-A ${ }^{3}$ & $11 / 28 / 84$ & $\mathrm{HB}$ & 288 & 7100 & 34,490 & 2086 & 204 \\
\hline Kapoho State $8^{3}$ & $8 / 18 / 92$ & $\mathrm{SC}$ & 350 & (17) & (425) & $(2.8)$ & nd \\
\hline Blue Grotto crack & 1941 & VI & $29-32$ & 1017 & nd & nd & nd \\
\hline Elemakule spring & $6 / 1 / 92$ & VI & 43 & 8365 & 14.7 & 3270 & 360 \\
\hline Burgess pool & 9/17/92 & VI & 33 & 2729 & 16.5 & 3100 & 321 \\
\hline Lighthouse spring & $8 / 14 / 91$ & VI & 29 & 1821 & 16.3 & 3440 & 276 \\
\hline Opihikao spring & $8 / 1 / 61$ & VI & 38 & 4800 & nd & nd & nd \\
\hline Pohoiki spring & $8 / 4 / 91$ & VI & 35 & 3011 & 15.8 & 3630 & 292 \\
\hline Pohoiki spring & $9 / 15 / 92$ & VI & 34 & 4441 & 16.7 & 3800 & 311 \\
\hline Vacationland spring & $8 / 14 / 91$ & VI & 32 & 2168 & 15.4 & 3740 & 261 \\
\hline Campbell spring & $8 / 3 / 91$ & VI & 37 & 3505 & 17.2 & 3400 & 280 \\
\hline Green Lake & $8 / 14 / 91$ & $P$ & 26 & 31 & 2.8 & 1550 & 443 \\
\hline
\end{tabular}


Table 2.--Chloride concentrations and ionic ratios--continued

${ }^{1}$ Data references are Thomas and others (1979) for Pulama well; Iovenitti (1990) for TH4; Kroopnick and others (1978) for Allison well; Swain (1973) for Malama-ki well; Thomas (1984) for the Kapoho Airstrip well; Stearns and Macdonald (1946) for Blue Grotto; Druecker and Fan (1976) for anchialine pond at Opihikao, DLNR data base for Orchidland well, and Hem (1986) for sea water.

2 Downhole samples collected during drilling near water table (Kapoho State 1 and Kapoho State 1A) or from 2270 foot depth (HGP-A) per Iovenitti (1990).

${ }^{3}$ For HGP-A, Kapoho State 3, and Kapoho State 1A, values shown are based on concentrations in separated liquid at the wellhead, corrected for steam flash and added steam using a reservoir enthalpy estimate based on the listed quartz geothermometer temperature corrected to liquid water at depth (GeothermEx, 1992; Janik and others, 1994). For Kapoho State 8, values in ( ) are based on concentrations in separated liquid derived from steam condensate (Geothermex, 1992).

${ }^{4}$ Water type: I=cold, dilute; II=cold, brackish; III=warm, dilute; IV=warm, brackish; V=hot, saline; $\mathrm{VI}=$ warm, brackish; $\mathrm{HB}=$ hot brine; $\mathrm{SC}=$ steam condensate; $\mathrm{P}=$ perched.

${ }^{5}$ Flowing water temperature, except for values in ( ) which were estimated from temperature profiles. Temperatures listed for MW2 were measured at land surface in a bailer. Reservoir temperature for KS 8 is that for saturated steam at the enthalpy of the discharge (Janik and others, 1994).

${ }^{6}$ Boron values for Pahoa Battery 2A, Kapoho Shaft, Keauohana 1, and Green Lake samples are near detection limit $(0.02 \mathrm{mg} / \mathrm{L})$ because of dilution. 
grouping the ground-water occurrences into six water-type categories, as discussed in the next section.

In deference to common usage, features labeled as springs are actually anchialine ponds, which are areas where the ground-water table is at the land surface in porous lavas or in lava tubes near the coast (Chai and others, 1989). Although anchialine ponds have no surface connection to the sea, they show tidal fluctuations and contain brackish water. The elevated temperatures $\left(29-38^{\circ} \mathrm{C}\right)$ of many of the ponds along parts of the southeast coast of the Island of Hawaii indicates that they contain a component of heated ground water. Anchialine ponds were sampled at low tide and as far back into the pool or lava tube as possible, in order to minimize mixing with sea water. In no case was it possible to estimate the rate of inflow of heated ground water. Infrared surveys (Fisher and others, 1966) indicate offshore discharge of both heated ground water and ground water cooler than ocean temperatures in many areas along the southeast coast; none of these features have been sampled. The feature named Blue Grotto (figs. 2A and 2B) was formerly an area near the base of the Puu Kukae cinder cone northeast of Kapoho Crater where warm $\left(29-32^{\circ} \mathrm{C}\right)$ water with chloride concentrations near $1,000 \mathrm{mg} / \mathrm{L}$ was observed in cracks in the lava (Macdonald, 1973). The land surface in this area is now at elevations of about $100 \mathrm{ft}$ above sea level, having been covered by lava during the 1960 Kapoho eruption. 


\section{TYPES OF GROUND WATER IN STUDY AREA}

Six basic types of ground water are encountered in shallow wells in and adjacent to the LERZ. These water types are distinguished on the basis of temperature, chloride concentration, and various element ratios (table 2). The six ground-water types are:

Type I: Cold $\left(25^{\circ} \mathrm{C}\right.$ or less), dilute $(\mathrm{Cl} 10 \mathrm{mg} / \mathrm{L}$ or less $)$; for example, the Pahoa Battery $2 \mathrm{~A}$ well Type II: Cold $\left(25^{\circ} \mathrm{C}\right.$ or less), brackish $(\mathrm{Cl}$ about $75-300 \mathrm{mg} / \mathrm{L})$; for example, the Kapoho Shaft well

Type III: Warm (about $40^{\circ} \mathrm{C}$ ), dilute $(\mathrm{Cl}$ about $20 \mathrm{mg} / \mathrm{L}$ ); for example, the MW1 well

Type IV: Warm (about $40^{\circ} \mathrm{C}$ ), brackish $(\mathrm{Cl}$ about $100-800 \mathrm{mg} / \mathrm{L})$; for example, the Allison well

Type V: Hot $\left(50-100^{\circ} \mathrm{C}\right)$, saline $(\mathrm{Cl} 1,000 \mathrm{mg} / \mathrm{L}$ or greater $)$; for example, the $\mathrm{TH} 3$ well

Type VI: Warm $\left(30-40^{\circ} \mathrm{C}\right)$, saline $(\mathrm{Cl} 1,000 \mathrm{mg} / \mathrm{L}$ or greater $)$; for example, the Pohoiki spring

The areal distribution of these water types is shown by symbols in figure 5. Type I waters are found north of the ERZ and represent the basal freshwater lens. Type II waters occur near the coast within the mixing zone between basal freshwater and saltwater. Type III waters are encountered in two closely spaced wells drilled just north of the PGV production/injection wells, and might represent freshwater that is heated by steam condensate from the geothermal system. Water from these wells (MW1 and MW3), although dilute, contains relatively high concentrations of $\mathrm{CO}_{2}$ and $\mathrm{H}_{2} \mathrm{~S}$ (unpublished analyses by PGV). Type IV waters are encountered in wells located east of the PGV lease inside and south of the LERZ. Type V waters, the hottest and most concentrated ground water in the study area, are found in wells drilled on and south of the PGV lease. Some wells encounter elevated temperatures and chloride concentrations within the ground-water system (for example, HGP-A and Kapoho State 1) and much higher temperatures and salinities in the underlying geothermal system. Type $\mathrm{V}$ ground water is shown at the locations of the Ashida well and wells TH1 and TH2, on the basis of temperatures measured in the upper $500-1,000 \mathrm{ft}$, and a chloride concentration of $460 \mathrm{mg} / \mathrm{L}$ in a sample bailed from a depth of $800 \mathrm{ft}$ in the Ashida well. TH1 and TH2, drilled to depths of 178-556 ft, did not reach the local water table.

Waters in the warm $\left(29-38^{\circ} \mathrm{C}\right)$ anchialine ponds along the coast are classified as Type VI ground water, and might contain mixtures of heated seawater and nonthermal meteoric water (Janik and others, 1994). Chloride concentrations in the samples collected from the ponds along the southeast coast range from about 1,800 to $4,800 \mathrm{mg} / \mathrm{L}$, but $\mathrm{Cl} / \mathrm{Br}$ ratios $(\sim 300)$ and $\mathrm{Cl} / \mathrm{B}$ ratios $(\sim 4,000)$ are similar to seawater values. Warm $\left(43^{\circ} \mathrm{C}\right)$ water sampled from $\mathrm{Na}$ Puu o na Elemakule, a littoral cone south of the southwest rift zone (fig. 4), contained twice as much chloride but similar elemental ratios as the warm water sampled from the anchialine ponds along the southeast coast (table 2). A larger seawater component in the Na Puu o na Elemakule sample is consistent with the fact that discharge from this feature occurs below sea level.

$\mathrm{Cl} / \mathrm{Mg}$ ratios in samples from the anchialine ponds along the southeast coast (15.4-17.2) are 


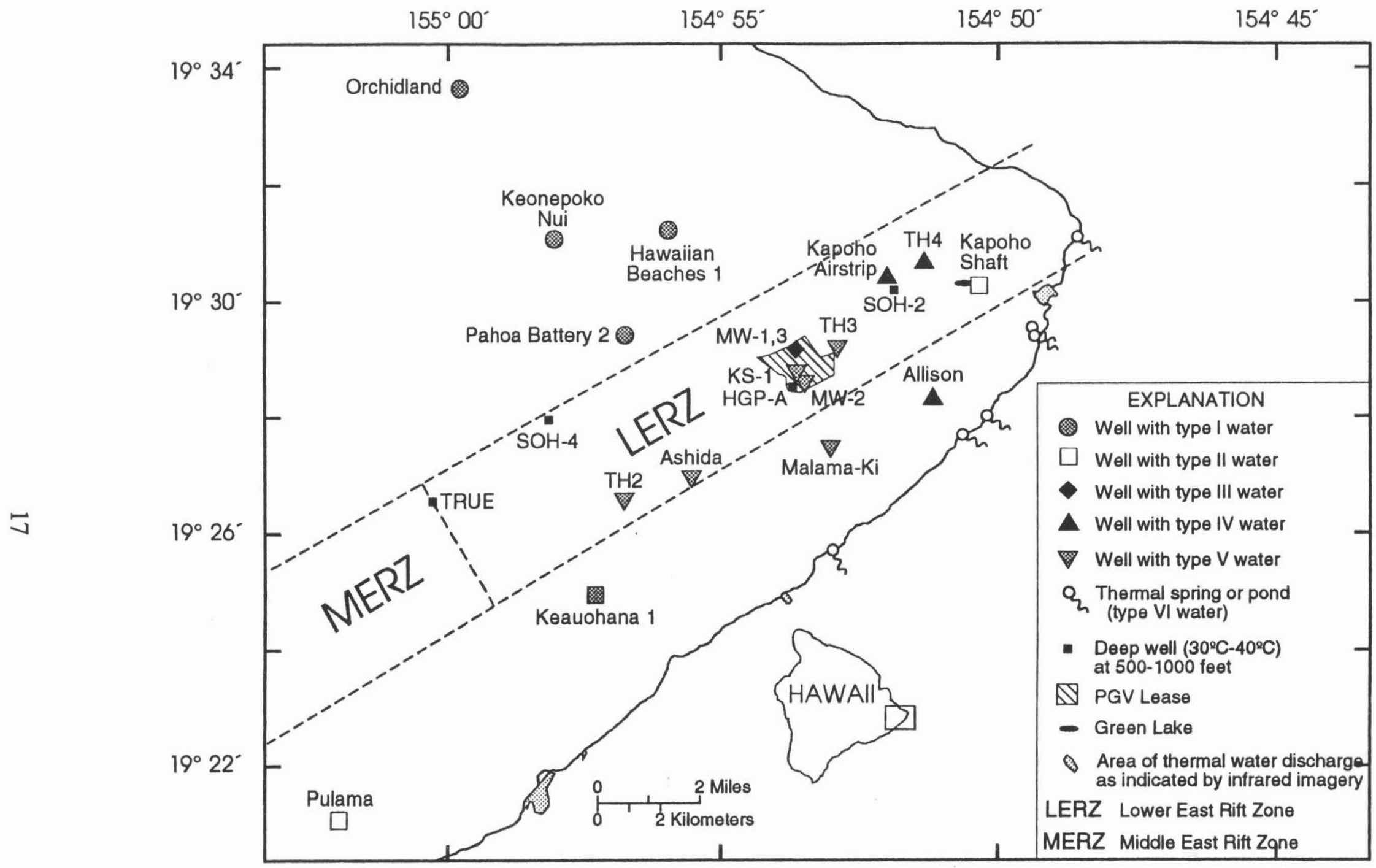

Figure 5. Wells tapping different types of shallow groundwater, distinguished on the basis of temperature and chloride content (see text). Well locations correspond to those shown and named in figure 4. Some deep geothermal wells are shown as encountering Type $\mathrm{V}$ ground water, based on temperatures and water chemistry of fluids encountered in the upper $500-1,000$ feet. 
slightly higher than the sea-water value (14). Loss of $\mathrm{Mg}$ due to various hydrothermal reactions could cause an increase in $\mathrm{Cl} / \mathrm{Mg}$ with increasing ground-water temperature (Cox and Thomas, 1979). $\mathrm{Cl} / \mathrm{Mg}$ ratios in Type IV and $\mathrm{V}$ ground waters are also higher than the seawater value. Experimental and theoretical observations indicate that $\mathrm{Mg}$ loss in seawater becomes significant at temperatures as low as $60^{\circ} \mathrm{C}$ (Seyfried and Bischoff, 1979; Bischoff and Seyfried, 1978). Generally, increased ground-water temperature results in an increased $\mathrm{Cl} / \mathrm{Mg}$ ratios for the thermal ground waters. Hot brines sampled from the PGV wells, for which $\mathrm{Cl} / \mathrm{Mg}$ values are greater than 1,000 , also follow this relation. Within each group of features, however, there is no consistent relation between temperature and $\mathrm{Cl} / \mathrm{Mg}$. This indicates that other factors also influence $\mathrm{Cl}$ and $\mathrm{Mg}$ concentrations.

Janik and others (1994) present more detailed comparisons of chemical and isotopic characteristics of thermal ground waters from this region. For the warm anchialine ponds, they favor a boiling-spring mixing model that includes a $165^{\circ} \mathrm{C}-180^{\circ} \mathrm{C}$ reservoir from which seawater rises, boils to $100^{\circ} \mathrm{C}$, and then mixes with cold dilute water. Types IV and V thermal ground waters in wells in the LERZ and to the south might be part of separate, less vigorous flow systems. The latter inference is based on higher $\mathrm{Cl} / \mathrm{Mg}$ ratios in the well waters and different estimated isotopic values for the cold-water mixing fraction. A seawater origin for thermal ground water in the study area is confirmed by $\mathrm{Cl} / \mathrm{Br}$ ratios of about 300 and $\mathrm{Cl}$ as compared with $\mathrm{Br}$ concentrations which follow a seawater dilution line. Heated saline ground water beneath the basal freshwater lens within the ERZ could occur within a conductive halo around the higher temperature geothermal system currently being developed. Alternatively, there might be a separate geothermal reservoir at temperatures near $165^{\circ} \mathrm{C}-180^{\circ} \mathrm{C}$ within or adjacent to the ERZ which is heated by dike intrusions and has yet to be delineated by deep drilling.

Two wells are listed for the Kapoho Crater area in the DLNR data base (3080-01, 02). There is actually only one well, a large-diameter collection gallery with two pumps. We refer to this as the Kapoho Shaft. The Kapoho Shaft, located near the eastern base of Kapoho Crater, taps basal ground water with elevated chloride but a $\mathrm{Cl} / \mathrm{Br}$ ratio equal to seawater, and hence is labeled as encountering Type II ground water. Chloride concentrations increase as the well is pumped, indicating inflow of seawater (Bill Sewake, DWS, oral commun., 1993). Water in the adjacent crater lake (Green Lake), which is only about $10 \mathrm{ft}$ deep with a water-surface elevation of about $20 \mathrm{ft}$, does not appear to be hydraulically connected with either the ocean or with the aquifer tapped by the Kapoho Shaft well, although its chemical composition resembles that of diluted seawater (Janik and others, 1994).

The deepest PGV wells, typified by $\mathrm{KS} 1 \mathrm{~A}$ and $\mathrm{KS} 3$, produce hot acidic brines with extremely high $\mathrm{Cl} / \mathrm{Mg}$ ratios due to the $\mathrm{Mg}$ loss noted above. In contrast, $\mathrm{Cl} / \mathrm{Br}$ ratios for these brines are close to that of seawater. Thus, it is likely that this fluid is essentially heated seawater which has undergone various high-temperature reactions with the basaltic rocks which have altered its $\mathrm{Cl} / \mathrm{Mg}$ and $\mathrm{Cl} / \mathrm{B}$ ratios. The low $\mathrm{pH}(2-3)$ measured in the liquid fraction produced from these wells (see Janik and others, 1994 for complete listing of historical sample analyses) probably results from loss of $\mathrm{Mg}(\mathrm{OH})_{2}$ during boiling in the reservoir and/or in the well bore. The corrosive nature of such fluid could pose problems for casing and surface pipe integrity if it were produced for power generation. 
Reservoir chloride concentrations, calculated from well-head sample conditions using the quartz geothermometer to correct for steam flash and accounting for steam added beyond that from isoenthalpic boiling (Janik and others, 1994; GeothermEx, 1992), are about 17 percent less than the seawater value of $19,000 \mathrm{mg} / \mathrm{L}$ for $\mathrm{KS} 1 \mathrm{~A}$. A reservoir temperature of $310^{\circ} \mathrm{C}$ is inferred from the well-head samples for KS 1A. Similar computations for the KS 3 samples yield reservoir chloride and temperature estimates of $30,300 \mathrm{mg} / \mathrm{L}$ and $318^{\circ} \mathrm{C}$, respectively (Janik and others, 1994). This indicates that the KS 3 reservoir fluids have undergone significant boiling in the formation, and might have been similar to KS 1A fluids before boiling.

The shallower PGV wells, KS 8, KS 9, and KS 10, tap high-temperature steam and gas in a steeply dipping fracture zone that most likely extends downward to the brine reservoir. This northward dipping fracture zone forms the current production reservoir supplying the PGV powerplant from wells KS 9 and KS 10. As noted by Thomas and others (1991) and Ingebritsen and Scholl (1993), pressures in this zone are near 1,900 psi (134 bars) and as such exceed local hydrostatic pressures at depths near $1,000 \mathrm{ft}$ by about $670 \mathrm{psi}$ (47 bars, or $1,540 \mathrm{ft}$ of cold water head). A continuous steam zone under near vapor-static pressure conditions might extend downward to a boiling zone, perhaps the zone tapped by the deeper well KS 3. Steam condensate from the PGV powerplant is currently injected into the brine reservoir via wells $\mathrm{KS}$ $1 \mathrm{~A}, \mathrm{KS} \mathrm{3}$, and KS 4. Additional information collected during continued operation of the PGV well field and during future geothermal well drilling and testing will be required to evaluate the degree of hydraulic connection between these two zones and to document production-related changes in subsurface conditions and in the chemistry and enthalpy of produced fluids.

The HGP-A well, drilled in 1976 , encountered temperatures as high as $360^{\circ} \mathrm{C}$ and produced two-phase fluid on a more-or-less continuous basis between 1976 and 1989 (Thomas, 1987). Changes in the chemistry of produced fluids with time and results of pre-production downhole sampling indicate that HGP-A taps more than one feed zone and that the low-salinity fluid initially produced $(\sim 1,000 \mathrm{mg} / \mathrm{L}$ chloride) was a mixture of more concentrated brine and steam from a low-permeability zone near the bottom of the well. Chloride concentrations had stabilized by about 1984 at values near $9,500 \mathrm{mg} / \mathrm{L}$ in separated liquid, or $7,100 \mathrm{mg} / \mathrm{L}$ in the downhole liquid (Janik and others, 1994). The evolution of chemistry in the HGP-A samples was toward the type of high-temperature diluted seawater encountered in well KS 1A (Janik and others, 1994).

Shallow downhole samples were obtained from KS 1 and KS 1A by bailing when the wells first encountered the ground-water system (table 2). The shallow sample listed for HGP-A was obtained from a depth of $2,270 \mathrm{ft}$ after the well had been completed and soon after an injection test had been performed (Kroopnick and others, 1978), and hence is a less reliable indicator of conditions within the ground-water system. The shallow samples from all three of these wells show salinities and temperatures representative of Type $\mathrm{V}$ water.

Although the general chemical characteristics of shallow thermal ground waters in the study area are similar to, but more dilute than, those of the deep geothermal reservoir fluids, significant differences in the degree of depletion of magnesium and sulfate indicate that little of the deep reservoir fluid leaks into the shallow ground-water system (Janik and others, 1994). Fluids sampled by the shallow thermal wells might have a component of geothermal water that has 
circulated to greater depths, especially those from the relatively hot $\left(93^{\circ} \mathrm{C}\right)$ TH3 well, but it is chemically distinct from the liquid found in the deep wells. As pointed out by Janik and others (1994), this is consistent with the generally closed nature of a reservoir developing a steam zone under vapor-static pressure conditions. There are, however, indications that steam condensate and non-condensible gas from this steam zone leak into the ground-water system where Type III waters are encountered in wells MW1 and MW3.

Dike-impounded ground water within the ERZ was encountered in the SOH-4 and True MidPacific wells, and in the Keller well at Kilauea summit (fig. 4). No data are available on fluid chemistry for the True well, and attempts to sample SOH-4 during drilling yielded only drilling mud. Thus, the only chemical data for this region is from bailer samples obtained from the Keller well (Tilling and Jones, 1991; Ingebritsen and Scholl, 1993). Samples collected in 1974 and 1975 from just below the water level contained $83-110 \mathrm{mg} / \mathrm{L} \mathrm{Cl}$, with $\mathrm{Cl} / \mathrm{Mg}$ ratios near 1 . Deuterium values for samples from this well indicate recharge elevations somewhat above that of Kilauea summit (Scholl and others, 1993; McMurtry and others, 1977), whereas deuterium values in Type $\mathrm{V}$ ground waters in the LERZ are much heavier and indicate a large component of sea-water origin (Janik and others, 1994). 


\section{RATES AND DIRECTIONS OF GROUND-WATER FLOW}

The water-level data compiled in table 1 can be used to construct a water-level contour map as an aid in delineating rates and directions of fluid flow within the shallow ground-water system in the study area. Previous attempts at contouring available water-level data (Takasaki, 1994; Imada, 1984) were limited by a lack of data within the LERZ. Although our data set is somewhat more detailed in this regard, any quantitative interpretation of ground-water flow in this region is complicated by (1) multiple fluid sources that give rise to significant differences in temperature and chemistry, (2) large differences in permeability related to dikes and other intrusive bodies, and (3) influences of fresh-water/salt-water interfaces. Faults and fracture zones oriented along the trend of the rift zone and transverse to the rift zone might also influence lateral and vertical fluid flow, but are thus far poorly delineated by available drill hole and geophysical data.

For the purposes of this report, representative values of water level elevation in wells for which such measurements have been made were used to develop the contour map shown in figure 6. Water levels range from $3 \mathrm{ft}$ to $20 \mathrm{ft}$ above sea level, except for the part of the rift zone that includes SOH-4 and the True Mid-Pacific well. For SOH-4, we have chosen to use the deeper water level values (about $150 \mathrm{ft}$ ) representative of conditions at depths near 2,300 ft. The waterlevel of $518 \mathrm{ft}$ for the True well was inferred from post-drilling pressure surveys. Although both of these wells are within the LERZ, as defined loosely by Swanson and others (1976) to extend to Heiheiahulu cone ( 1 mile southeast of the True well), they tap dike-impounded water at elevations hundreds of feet above water levels in the surrounding region.

In parts of the study area, the water-level data can be contoured without discontinuity across or within the rift zone. As indicated by previous authors, ground water flows dominantly northeastward north of the LERZ and southeastward south of the rift. Within the part of the LERZ east of HGP-A, ground-water flow is primarily downrift to the northeast, although the data also indicate an eastward component of flow toward the warm coastal ponds. We caution, however, that this interpretation is based on relatively small differences in water levels among a few wells spaced several miles apart and variations in water level measured at each well are of the same order as the differences contoured here. Water-level gradients (difference in water level/distance) are 1-4 ft/mi north of the rift, about $1.5 \mathrm{ft} / \mathrm{mi}$ south of the rift, and $1-15 \mathrm{ft} / \mathrm{mi}$ within the part of the LERZ east of HGP-A. The average gradient in the apparent zone of southeasterly flow originating near the PGV lease is about $3 \mathrm{ft} / \mathrm{mi}$. It is assumed that these gradients apply to the shallow unconfined ground-water system within which the effects of volcanic dikes in restricting ground-water flow are relatively minor.

Water levels and gradients are poorly constrained to the southwest of HGP-A. Water-level gradients appear to steepen as the rift is approached from the south, indicating a decrease in transmissivity, but the available data are too sparse to delineate whether this occurs inside or outside of the surface expression of the rift.

An apparent water-level gradient of $165 \mathrm{ft} / \mathrm{mi}$ is indicated between the True and SOH-4 wells. Even higher gradients can be inferred for the UERZ and MERZ from water levels near 2,000 ft above sea level measured in the Keller well at Kilauea summit (Ingebritsen and Scholl, 1993; 


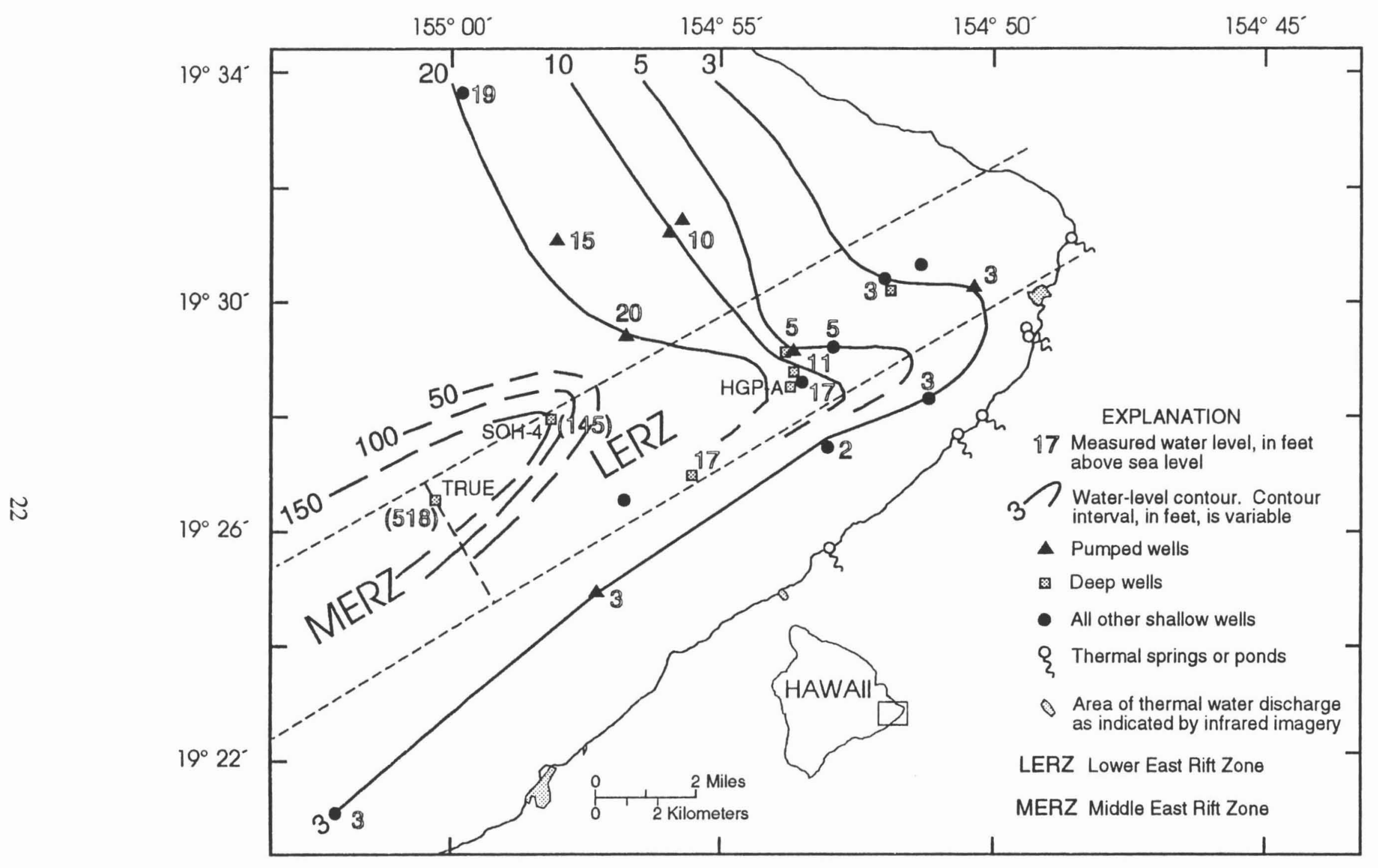

Figure 6. Water-level contours and representative water levels measured in wells tapping basal ground water in the study area. Water-levels shown in parentheses are based on post-completion pressure surveys (True Mid-Pacific well) or measurements made during drilling at depths near 2,300 feet (SOH-4). 
Keller and others, 1979) and water levels inferred from electrical resistivity data summarized by Kauahikaua (1993). These observations indicate that ground water could flow downrift from the summit region to the LERZ, but that the transmissivities in parts of the rift west of SOH-4 must be significantly lower than values in the part of the rift east of SOH-4. Downrift ground-water flow through the UERZ and MERZ is also required to remove some or all of the large amount of recharge from infiltration of rainwater falling over this region. The decrease in static water level during the drilling of the upper $1,150-2,700 \mathrm{ft}$ of $\mathrm{SOH}-4$ indicates that there is also a gradient for downward flow in the dike-impounded parts of the rift. Dike frequency increased significantly below a depth of 3,000 ft (Novak and Evans, 1981), possibly corresponding to a lower limit to ground-water flow in this area. Tritium data for ground water from the Kilauea region (Scholl and others, 1993) indicate somewhat longer residence times for shallow ground waters sampled in the LERZ and to the south than for ground water to the north of the LERZ. Some ground water might also flow southward from the MERZ and UERZ to the coast. Considerable additional hydrologic information from drill holes is needed, however, before rates of ground-water flow within these dike-impounded parts of the ERZ can be reliably determined.

Several zones of low electrical resistivity extend southeastward from the MERZ and the LERZ (Kauahikaua, 1993; Jackson and Kauahikaua, 1987; Flanigan and Long, 1987). These zones may reflect the flow of saline, thermal ground water from the rift toward the coast, as evidenced in part by the occurrence of warm anchialine ponds and thermal infrared anomalies along the southeast coast. Such thermal water may be encountered in the Malama-ki, TH3, and MW2 wells. Samples from these wells indicate that the thermal water originates in part from seawater that is conductively heated, which causes it to flow upward from beneath the basal freshwater lens.

Although estimates of the hydraulic conductivity of the dike-free Kilauea lavas have been given by various authors, there are few actual measurements to substantiate these estimates. Imada (1984) modeled ground-water flow in the Puna area and matched a relatively sparse waterlevel data set using hydraulic conductivity values of about $15,000 \mathrm{ft} / \mathrm{d}$ in non-rift areas, $3,000 \mathrm{ft} / \mathrm{d}$ in parts of the LERZ east of HGP-A, and $30 \mathrm{ft} / \mathrm{d}$ between HGP-A and the location of SOH-4. The amount of water flowing through this model was set by assumed recharge rates from local precipitation. Takasaki (1994) calculated hydraulic conductivity values from measured and estimated water-level gradients and estimated rates of recharge to the ground-water system in and adjacent to the ERZ. His results include values of 3,000-9,000 ft/d for dike-free lavas in the LERZ, 6,000 ft/d north of the LERZ, 3,000 ft/d south of the LERZ, and 5-30 ft/d in the MERZ and UERZ. Takasaki (1994) calculated a total recharge rate of $230 \mathrm{Mgal} / \mathrm{d}$ for the ERZ from precipitation less evapotranspiration, and assumed that all this infiltrated water enters the groundwater system and flows downrift to the ocean. A few direct measurements of hydraulic properties from well tests and modelling of coastal tidal signals indicate hydraulic conductivity values of 3,000-13,000 ft/d outside the LERZ and 300-1,300 ft/d inside the LERZ (M\&E Pacific, Inc., 1987; S. Gingerich, University of Hawaii, written commun., 1993).

Estimates of darcy velocity, or specific discharge, can be obtained by multiplying hydraulic conductivity times water-level gradient. On the basis of the results discussed above, reasonable estimates of darcy velocity would range from about 1-10 ft/d for dike-free regions to less than 0.1-1.0 ft/d for regions where dike-impoundment is significant. Particle velocities (darcy velocity divided by porosity), which are more indicative of potential rates of contaminant transport, might 
be at least 10 times greater than these values. Estimated average particle velocities of 2-8 ft/d outside the LERZ have been attributed by several authors to Davis and Yamanaga (1968), but these authors do not, in fact, make such estimates. Imada (1984) modeled ground-water velocities of 0.1 to $11 \mathrm{ft} / \mathrm{d}$ in the lower part of the east rift zone - the higher values being applicable to the region east of HGP-A. 


\section{GROUND-WATER USE}

Water is currently being pumped from seven large-capacity wells for domestic use (tables 1 and 3 and figs. 2A and 2B). Five of these wells are operated by the Department of Water Supply and two are operated by private water companies. With the exception of the Kapoho Shaft, all of these wells are located outside the LERZ. Information on water usage from these wells was provided by DLNR (Glenn Bauer) and DWS (Curino Antonio). The range of average monthly pumpage for each well over the $1988-92$ period is listed in table 3 . The combined production from all of these wells averages about $800 \mathrm{gal} / \mathrm{min}$, and about 80 percent of this production occurs north of the rift in Pahoa and nearby developments. Although wells of high productivity (greater than $300 \mathrm{gal} / \mathrm{min}$ ) have been drilled in the LERZ (table 1), all have encountered warm temperatures or high concentrations of chloride or both.

The DWS supplies freshwater to customers from three systems of wells - the Pahoa, Kalapana, and Kapoho systems - and associated transmission lines. The Pahoa system supplies about 2,400 people through 787 service hookups; the combined service hookups of the Kapoho and Kalapana systems is only 91 . Ground water is also supplied to about 1,100 service hookups in housing subdivisions northeast of Pahoa by the Hawaiian Beaches and Hawaiian Shores wells, operated by a private water company and a community association, respectively. A DWS water transmission line that extends southeastward from Pahoa connects near Pohoiki with the transmission line extending southward from the Kapoho well, and DWS plans to utilize the Pahoa wells to supply the area currently served by the Kapoho Shaft well. Future water requirements on the Pahoa supply system will increase if a proposed golf course and housing development near Pohoiki are built.

Rain catchment systems are commonly used for water supply in areas not serviced by county wells or other water company wells and as backups in the event of failures of well supply systems. Contacts made with state agencies (DLNR and Department of Health) and with the county DWS indicate that there are no maps or organized inventories of locations of such catchment systems. It is reasonable to assume that most houses and many public buildings in the study area have catchment systems, but that the primary source of freshwater is ground water from wells.

Water requirements for the existing PGV geothermal development have thus far been minimal. Although two wells were drilled for water supply (MW1 and MW3), most of the water consumption for drilling and plant operations has so far been provided by the DWS Pahoa well system because of its lower temperature and gas content. Under normal operations, significant water supply is needed only for air-mist drilling in the upper $2,000 \mathrm{ft}$ or so where circulation losses can be substantial. Flow rates of about $60 \mathrm{gal} / \mathrm{min}$ per well might be required for this purpose over a period of a few weeks. Siting ground-water wells for drilling and blowout control at or near future development sites in the LERZ and MERZ might prove difficult in view of conditions encountered on the PGV lease (warm temperature) and near SOH-4 (low permeability). Freshwater for drilling operations on the SOH-4 and True Mid-Pacific wells was obtained from a combination of rainfall collected locally in drilling ponds and water hauled to the drill sites in tanker trucks. Assuming a total water requirement of 1.2 million gallons for drilling a geothermal well, about 100 tanker trips would be needed to supply all this water. 
Table 3. Monthly average pumping rates for ground-water wells in the study area

[Values shown are based on data on file with the Department of Water Supply of Hawaii County and the Department of Lands and Natural Resources]

\begin{tabular}{|c|c|c|c|c|}
\hline \multirow[b]{2}{*}{$\begin{array}{l}\text { Well } \\
\text { (Number) }\end{array}$} & \multirow[b]{2}{*}{ Owner $^{1}$} & \multirow[b]{2}{*}{$\begin{array}{l}\text { Time } \\
\text { Period }\end{array}$} & \multicolumn{2}{|c|}{$\begin{array}{l}\text { Average Monthly Pumpage } \\
\text { gallons per minute }\end{array}$} \\
\hline & & & Range & $\begin{array}{l}\text { Overall } \\
\text { Average }\end{array}$ \\
\hline $\begin{array}{l}\text { Pahoa } 1,2 \\
(2986-01,-02)\end{array}$ & DWS & $1988-91$ & $127-323$ & 210 \\
\hline $\begin{array}{l}\text { Kapoho Shaft } \\
(3080-01)\end{array}$ & DWS & $1988-91$ & $21-85$ & 41 \\
\hline $\begin{array}{l}\text { Keauohana } 1,2 \\
(2487-01,-02)\end{array}$ & DWS & 1988-91 & $35-88$ & 52 \\
\hline $\begin{array}{l}\text { Keonepoko } \\
(3188-01)\end{array}$ & DWS & $1988-91$ & $0-200$ & 99 \\
\hline $\begin{array}{l}\text { Hawaiian Beaches } \\
(3185-01)\end{array}$ & MLWC & 1992 & $350-415$ & 380 \\
\hline $\begin{array}{l}\text { Hawaiian Shores } \\
(3185-02)\end{array}$ & HSCA & 1992 & $29-34$ & 33 \\
\hline
\end{tabular}

${ }^{1}$ DWS=Department of Water Supply (Hawaii County)

MLWC=Miller and Lieb Water Co., Inc.

HSCA=Hawaiian Shores Community Association. 
The capacity to pump large amounts of cold water to control geothermal well blowouts was recommended following a review of the blowout, or unplanned steam release, of KS 8 in June 1991 (Thomas and others, 1991). The review also suggests that a water supply at temperatures less than $24^{\circ} \mathrm{C}$ would be more effective than water from MW1 or MW3, which is about $40^{\circ} \mathrm{C}$. This would probably require piping water from wells outside the rift. However, experience at other geothermal fields suggests that blowouts can also be effectively controlled by injection of heavy mud rather than cold water (Don Campbell, Mesquite Group, Inc., oral commun., 1993).

The existing PGV plant is air cooled (forced draft) and hence involves no consumptive use of ground water. Should some future powerplants be designed for evaporative cooling, rather than air cooling, there would be additional requirements for cooling water. These could be supplied by steam condensate, local ground water, or rain catchment systems. Although it is difficult to determine how much cooling water would be required for individual developments, a rough estimate based on experience at other developed fields suggests consumptive use rates of $15-50 \mathrm{gal} / \mathrm{min}$ per $25 \mathrm{MW}$ plant, or $300-1,000 \mathrm{gal} / \mathrm{min}$ for the $500 \mathrm{MW}$ HGP.

Ground water might also be required for injection of produced gases in the event of plant shut-downs following disruption of the electrical distribution system (due, for example, to failure of the undersea cable). Under normal operation, such gases can be dissolved in steam condensate or produced liquid and then injected. If a powerplant were shut down but the production wells were still in operation, either a backup water supply would be needed for this purpose or gas would have to vented to the atmosphere. The PGV project description given by Clark and Stewart (1991) indicates that, in the event of a shut down of the entire powerplant, the wellfield production rate would be reduced to 30 percent of full flow and steam would be released through an emergency steam release facility in which 96 percent of the produced $\mathrm{H}_{2} \mathrm{~S}$ would be removed using sodium hydroxide. The PGV operating permit, however, calls for a water supply rate of up to $500 \mathrm{gal} / \mathrm{min}$ to dissolve and inject the produced gases. Alternatively, of course, all production and injection wells could be shut down following loss of the power distribution system. 


\section{POTENTIAL EFFECTS OF GEOTHERMAL DEVELOPMENT}

Ground-water resources in and adjacent to the east rift zone of Kilauea could be affected in several ways by the proposed Hawaii Geothermal Project. Potential effects include (1) changes in water level in wells caused by pumping of ground water to support geothermal development and/or operation of geothermal production and injection wells, (2) contamination of the groundwater system from leakage of geothermal fluids and gases, and (3) changes in discharge characteristics of warm anchialine ponds along the coast. Possible secondary effects on transportation systems may be associated with water hauling to parts of the ERZ where water requirements for geothermal operations cannot be met with rain catchment systems or groundwater wells. With currently available information, it is only possible to describe the conditions under which such effects could occur, and in some cases provide estimates of the possible magnitudes and time frames involved. Hydrologic monitoring of wells and surface features needs to accompany any future geothermal development in this region in order to better assess hydrologic changes.

\section{Changes Associated with Fluid Production}

The pumping of ground water to supply freshwater for various geothermal operations would cause some amount of drawdown that could lower water levels near existing water-supply wells. This effect would be minor in dike-free regions of Kilauea. For example, assuming a hydraulic conductivity of $7,000 \mathrm{ft} / \mathrm{d}$ in an unconfined fresh-water aquifer $50 \mathrm{ft}$ thick, a well being pumped continuously at $450 \mathrm{gal} / \mathrm{min}$ for as many as 30 years would cause a drawdown of less than 0.3 feet at a distance of 1 mile. Lowering the hydraulic conductivity by a factor of 10 increases the drawdown at this distance to about 1.2 feet after 30 years. Given the moderating influence of abundant recharge and the fact that water requirements associated with a typical $25 \mathrm{MW}$ development would involve substantially less than $450 \mathrm{gal} / \mathrm{min}$ on a continuous basis, it is doubtful that ground-water withdrawals in support of even 20 such developments would cause significant drawdown in adjacent public and private wells.

Ground-water pumping associated with future geothermal developments located in the LERZ to the northeast of the PGV lease could cause sea-water intrusion if wells were sited within a mile or two of the coast. In such situations, increases in salinity in existing wells near the development area might also occur.

In parts of the ERZ southwest of the PGV lease, it might not be possible to complete groundwater wells with enough capacity to supply cold freshwater for well drilling, blowout control, and powerplant operations. In this event, freshwater would have to be obtained from local rain catchment systems or from ground-water sources further to the east or outside the rift. Such water would have to be piped or hauled to the HGP sites. Water supply rates for well blowout control could place the greatest demand on such supply systems, although operational plans that rely on the use of drilling mud rather than cold water for blowout control could be used to minimize such demands.

As noted previously, water was hauled in for drilling operations on the SOH-4 and True Mid- 
Pacific wells. During the exploration phase of the HGP, simultaneous drilling operations for many such geothermal wells requiring water hauling could result in substantial effects on transportation systems, including construction of new roads and increased heavy-vehicle traffic on existing roads. Water transmission through pipelines might lessen this type of effect. Nevertheless, the degree of access to reliable ground-water supplies in proximity to HGP development sites could impose short- or long-term limits on the amount of geothermal exploration and development activity in this region.

To the extent that thermal fluid from geothermal reservoirs flows upward into the overlying ground-water system under pre-development conditions, there is a potential for changes in this rate of input and hence resultant changes in water levels (and fluid chemistry) in the shallow system. Geothermal fields in other parts of the world are typically situated near hot springs whose origin is related to thermal-fluid upflow and whose flow rates can be decreased by pressure declines accompanying geothermal fluid production. In the case of the LERZ, ground water at temperatures of $40-100^{\circ} \mathrm{C}$ appears to contain thermal components derived from heated seawater (Type IV and V ground water) or steam-heated freshwater (Type III ground water). Changes in pressure and temperature in shallow steam-filled reservoirs or deeper brine reservoirs induced by geothermal development could conceivably change the quantity and/or the temperature of these thermal components. However, the flow paths for thermal ground water in the ERZ are as yet insufficiently delineated to allow such changes to be predicted. Hydrologic monitoring of observation wells, as currently being carried out by PGV and the University of Hawaii, would be required to detect changes in either the temperature or the flow rate of thermal ground water moving through the rift zone. Potential effects of geothermal development on thermal water discharging in the warm coastal ponds are discussed in a later section.

\section{Ground-Water Contamination}

During both the well-drilling and power-production phases of the HGP, the potential exists for geothermal fluids to leak into the ground-water system, causing changes in chemistry and temperature. In dike-free regions of the LERZ, where aquifer transmissivity is high, rapid migration of contaminants is likely. However, abundant recharge to the ground-water system in such regions would act to dilute contaminant concentrations. Imada (1984), for example, modeled the movement of thermal water injected at different concentrations into the ground-water system in the vicinity of the HGP-A well, with fresh-water recharge specified at a constant rate, and found that only for relatively saline injectate $(\mathrm{Cl} 10,000 \mathrm{mg} / \mathrm{L}$ or greater) did significant increases in chloride concentrations occur at downstream wells.

Wells currently supplying the PGV powerplant produce low salinity steam/water mixtures and gas. Leaks of this fluid into the ground-water system through casing breaks or during well drilling operations would pose little threat of increased salinity in the ground-water system, but could produce increases in temperature and acidity. Acid ground-water conditions could cause severe casing corrosion at the water table, as noted by GeothermEX (1992). During normal operations, produced gases are to be re-dissolved under high pressure in the injected water, but there would be the possibility of gas breakout from injection wells into shallow aquifers. These risks could be minimized through proper specifications of well completion and casing design 
criteria. However, the long-term effects of gas accumulation in injection zones, which for the PGV well field is located below the production zone, cannot as yet be predicted.

Production and injection for the HGP might in some cases involve different types of fluids than those currently utilized in the PGV operation. Even within the PGV lease area, data from the production history of the HGP-A well indicate that salinities could increase with time as different fluids are tapped by production. It remains to be seen whether future well fields completed for the HGP will tap steam-filled fracture zones or high-temperature brine reservoirs, or whether initial conditions will change significantly during production.

As discussed in a previous section, ground-water velocities in the dike-free parts of the rift zone might be as great as $10 \mathrm{ft} / \mathrm{d}$ or more. Under such conditions, contaminants could move distances of several miles in a period of a few years. For example, the numerical simulations by Imada (1984), involving injection of saline water at about $13 \mathrm{gal} / \mathrm{min}$ near HGP-A, predicted significant increases in concentrations of chloride at distances of several miles after 25 years. No results were given for concentration changes over shorter time frames. Although lava tubes are known to exist in this region, there is no evidence from wells drilled in or adjacent to the LERZ for the existence a network of such conduits that could allow very rapid movement of ground-water contaminants over large distances. It is likely that such conduits are for the most part blocked by collapse.

Chloride concentrations and $\mathrm{Cl} / \mathrm{Mg}$ ratios measured in downhole samples collected in 1991 and 1992 from well MW2 show increases from about 500 to $1,100 \mathrm{mg} / \mathrm{L}$ and 30 to $100 \mathrm{mg} / \mathrm{L}$, respectively (table 2 and PGV monitoring reports). Variations in chloride of this magnitude are observed in other wells (for example, TH3 - table 1), but no consistent trends exist. Downhole temperatures measured on a daily basis in MW2 rose and fell by about $7^{\circ} \mathrm{C}$ in June 1991 ; subsequent, but less frequent, measurements indicate a long-term increase of about $10^{\circ} \mathrm{C}$ through 1992 (PGV monitoring reports). The timing of these changes at MW2 and the proximity of this well to KS 8 (1,000 ft away) indicate a possible relation between the MW2 chemical changes and the blowout of KS 8 in June 1991. Although the uncontrolled steam discharge at the KS 8 wellhead lasted for only 31 hours, temperature measurements indicate that steam continued to leak upward past the 13-inch casing shoe at 2,128 $\mathrm{ft}$ until the well was finally quenched and plugged several months later. Thus, any ground-water contaminant associated with the KS 8 blowout was most likely steam condensate. Although resultant temperature increases in MW2 would be expected, increases in salinity would not, unless the leakage of steam condensate (at relatively high pressure) mobilized more concentrated fluids around KS 8 to move toward MW2. An alternative explanation for the MW2 data is that ground-water temperatures and salinities were depressed in 1990 and early 1991 by a period of above normal rainfall and recharge, and subsequent changes in MW2 reflect the return to more normal conditions.

Nevertheless, apparent changes at MW2 demonstrate the potential for contamination of the ground-water system from geothermal wells, and suggests the need for long-term hydrologic monitoring to identify cause-and-effect relations. Presumably, the experience gained in drilling the PGV wells and the adoption of adequate casing and wellhead pipe inspection programs will reduce the chances for accidental release of thermal water at shallow depths. It is emphasized, however, that geothermal fluids in the form of steam condensate and heated seawater reach the 
ground-water system under natural conditions in the LERZ and contribute to the observed spacial variations in temperature and salinity in wells in and near the PGV lease. Indeed, the relatively poor quality and high temperature of shallow ground water in the LERZ indicate that the consequences of contamination in this area may not be important.

Directions of contaminant movement in the ground-water system can be estimated from the existing water-level data for parts of the LERZ and adjacent areas east of Pahoa. This information indicates that existing water-supply wells outside the rift are unlikely to be affected by accidental releases of contaminants at geothermal development sites in the eastern part of the LERZ. For HGP developments in the western part of the LERZ and in the MERZ, ground-water flow directions and aquifer properties are too poorly constrained to speculate as to the fate of contaminants. Hydrologic and chemical menitoring of observation wells installed at varying distances from each HGP development could provide baseline data to define the natural range of hydrologic and chemical conditions before power production begins.

\section{Changes in Warm Coastal Ponds}

Warm waters from the anchialine ponds along the southeast coast appear to be mixtures of fresh ground water and heated seawater derived from sources either within the LERZ or south of the surface expression of the rift (Janik and others, 1994). There is no evidence that these features contain components of high $\mathrm{Cl} / \mathrm{Mg}$ geothermal brines encountered in the deep PGV wells. Instead, their temperatures and chemical composition are more like those of wells tapping hot, saline ground water within and to the south of the LERZ. These considerations, along with the directions of ground-water flow inferred from the water-level contour map, indicate that the warm anchialine ponds discharge thermal ground water originating in the LERZ. The thermal component in this ground water is most likely derived from saline water that is heated by conduction (and, possibly, by steam condensation) and flows upward into the basal freshwater lens. There could be an intermediate-temperature $\left(165^{\circ} \mathrm{C}-180^{\circ} \mathrm{C}\right)$ saline reservoir present within the ERZ from which this thermal component is derived. This condition contrasts with more typical geothermal field settings in which thermal springs are derived from upflow and lateral outflow from the same hot-water reservoir that is being produced. In the latter case, reductions in reservoir pressure commonly result in reductions in the flow of nearby thermal springs. Reservoir conditions delineated thus far within the ERZ are somewhat different, in that the deep, high-temperature brine reservoir may only be in hydraulic connection with shallow thermal ground water through intermediate-level steam-filled fracture zones.

HGP geothermal developments in the ERZ might not involve the same type of reservoir conditions encountered by PGV and could conceivably develop either high-temperature (about $300^{\circ} \mathrm{C}$ ) or intermediate-temperature (about $180^{\circ} \mathrm{C}$ ) liquid reservoirs. Hydrologic connections between such reservoirs and thermal ground water discharging along the southeast coast are possible. Under such circumstances, pressure changes induced by development of geothermal reservoirs could cause decreases in flow and temperature of this thermal water. Once again, monitoring data (water levels, temperatures, fluid chemistry) from observation wells drilled along the expected flow paths would be required to evaluate such effects. 


\section{SUMMARY AND CONCLUSIONS}

The nature and occurrence of ground-water resources in and adjacent to the eastern part of the LERZ can be roughly determined from the available well and spring data. Although the existing 25 MW Puna Geothermal Venture development is not part of the proposed Hawaii Geothermal Project, information provided by this development, coupled with information on the surrounding ground-water system, allows an assessment of potential effects of the HGP on the ground-water resources of this part of the rift. This serves as a guide to assessment of potential effects of the HGP on ground-water resources within and adjacent to other parts of the ERZ.

Adequate supplies of fresh ground water are available from shallow aquifers in or adjacent to the rift to support geothermal development in the eastern part of the LERZ. Minimal effects on the quantity of ground water available for other users would be anticipated because of (1) relatively small long-term requirements for ground water to support geothermal development activities and (2) a highly transmissive ground-water system. Although thermal ground water is commonly encountered in shallow wells drilled in this part of the LERZ, water requirements for geothermal well drilling and blowout control, injection of produced gases, and powerplant operations could be supplied through a combination of wells drilled at each development site and wells drilled north of the rift. For geothermal developments elsewhere in the LERZ and the MERZ, the transmissivity and lateral continuity of freshwater aquifers are likely to be sufficiently reduced by the increased frequency of high-level dikes that adequate supplies of fresh ground water cannot not be locally obtained. Such needs would have to be met largely by importing water from sources outside the rift, that is, existing DWS wells or new wells drilled for this purpose. Under these circumstances, secondary effects associated with water hauling by truck and laying of water pipelines are likely to be of more significance than effects on the quantity of ground water available to other users.

Contamination of freshwater aquifers could occur from accidental release of geothermal fluids and gases either through well blowouts or casing breaks. Experience gained from the existing PGV development should allow delineation of adequate specifications for well drilling and well completion procedures so as to minimize the potential for such contamination. Although groundwater velocities in dike-free regions of the LERZ are relatively high, changes in chemistry and temperature downstream from points of contamination tend to be diminished by the diluting effects of recharge from local rainfall. Furthermore, existing utilization of fresh ground water occurs primarily north of the LERZ in regions of higher head where wells are more productive and water quality is better than in the rift and to the south of the rift. For developments in other parts of the rift zone, rates and directions of ground-water flow and chemical composition and gas content of potential geothermal reservoirs are as yet unknown. Movement of contaminants accidently released into the ground-water system in such areas would likely be restricted by low transmissivity and diluted by rainfall infiltration. Nevertheless, monitoring of water level, temperature, and water chemistry in observation wells, as currently carried out for the PGV

development, is needed for each HGP development to adequately assess potential effects of HGP operations on the groundwater resources of this region. 


\section{REFERENCES CITED}

Bischoff, J.L., and Seyfried, W.E., 1978 , Hydrothermal chemistry of seawater from $25^{\circ}$ to $350^{\circ} \mathrm{C}$ : American Journal of Science, v. 248, p. 838-860.

Chai, D.K., Cuddihy, L.W., and Stone, C.P., 1989, An inventory and assessment of anchialine pools in Hawaii Volcanoes National Park from Waha'ula to Ka'aha, Puna and Ka'u, Hawai'i: Cooperative National Park Resources Studies Unit, Department of Biology, University of Hawaii at Manoa, Technical Report 69, 37 p.

Clark, N.J., and Stewart, L.K., 1991, Developing the first commercial geothermal project in the Hawaiian Islands: Geothermal Resources Council Bulletin, v. 20, no. 5, p. 127-134.

Cox, M.E., and Thomas, D.M., 1979, Chloride/magnesium ratio of shallow groundwaters as a regional geothermal indicator in Hawaii: Hawaii Institute of Geophysics Technical Report HIG 79-9, $51 \mathrm{p}$.

Davis, D.A., and Yamanaga, George, 1968, Preliminary report on the water resources of the HiloPuna area, Hawaii: Hawaii Division of Water and Land Development, Department of Land and Natural Resources Circular C45, 38 p.

Davis, D.A., and Yamanaga, George, 1973, Water resources summary Island of Hawaii: Hawaii Division of Water and Land Development, Department of Land and Natural Resources Report R47, $42 \mathrm{p}$.

Deymonaz, J.E., 1991, Scientific observation hole \#4: unpublished technical report, 29 p.

Druecker, Michael, and Fan, Pow-foong, 1976, Hydrology and chemistry of ground water in Puna, Hawaii: Ground Water, v. 14, p. 328-338.

Epp, David, and Halunen, A.J., Jr., 1979, Temperature profiles in wells on the island of Hawaii: Geothermal Resources Exploration in Hawaii: Number 7, August 1979, Prepared for the National Science Foundation, Grant GI-38319, 31 p.

ENEL (Ente Nazionale per L'Energia Elettrica), 1990, The Kilauea east rift zone: geothermal evaluation of the existing data: draft report for the State of Hawaii, Department of Business and Economic Development, 103 p.

Fisher, W.A., Davis, D.A., and Sousa, T.M., 1966, Fresh-water springs of Hawaii from infrared images: U.S. Geological Survey Hydrologic Investigations Atlas HA-218.

Flanigan, V.J., and Long, C.L., 1987, Aeromagnetic and near-surface electrical expressions of the Kilauea and Mauna Loa volcanic rift systems in Decker, R.W., Wright, T.L., and Stauffer, P.H., eds., Volcanism in Hawaii: U.S. Geological Survey Professional Paper 1350, p. 935946.

GeothermEx, Inc., 1992, Annual report: Geothermal resources assessment: Report prepared for the State of Hawaii Department of Business, Economic Development, and Tourism, 240 p.

Hem, J.D., 1986 (2nd printing), Study and interpretation of the chemical characteristics of natural water: U.S. Geological Survey Water-Supply Paper 2254, 264 p.

Hunt, C.D., Jr., Ewart, C.J., and Voss, C.I., 1988, Region 27, Hawaiian Islands in Back, William, Rosenshein, J.S., and Seaber, P.R., eds. The Geology of North America, v. O-2, Hydrogeology: Boulder, Geological Society of America, p. 255-262.

Imada, J.A., 1984, Numerical modeling of the groundwater in the east rift zone of Kilauea Volcano, Hawaii: M.S. Thesis, University of Hawaii, Honolulu, 102 p.

Ingebritsen, S.E., and Scholl, M.A., 1993a, Annotated Bibliography: U.S. Geological Survey Open-File Report 93-551-D, 30 p. 
Ingebritsen, S.E., and Scholl, M.A., 1993b, The hydrogeology of Kilauea Volcano: Geothermics, p. 255-270.

Iovenitti, J.L., 1990, Shallow ground water mapping in the lower east rift zone, Kilauea Volcano: Geothermal Resources Council Transactions, v. 14, part 1, p. 699-703.

Jackson, D.B., and Kauahikaua, J.P., 1987, Regional self-potential anomalies at Kilauea Volcano in Decker, R.W., Wright, T.L., and Stauffer, P.H., eds., Volcanism in Hawaii: U.S. Geological Survey Professional Paper 1350, p. 947-959.

Janik, C.J., Nathenson, M., and Scholl, M.A., 1994, Geochemistry of spring and well waters on Kilauea Volcano, Hawaii and vicinity: U.S. Geological Survey Open-File Report (in preparation).

Kauahikaua, J.P., 1993, Geophysical characteristics of Kilauea Volcano's hydrothermal systems: Geothermics, p. 271-299.

Keller, G.V., Grose, L.T., Murray, J.C., and Skokan, C.K., 1979, Results of an experimental drill hole at the summit of Kilauea Volcano, Hawaii: Journal of Volcanology and Geothermal Research, v. 5, p. 345-385.

Kroopnick, P.M., Buddemeir, R.W., Thomas, D.M., Lau, L.S., and Bills, D., 1978, Hydrology and geochemistry of a Hawaiian geothermal system: HGP-A: Hawaii Institute of Geophysics report HIG-78-6, 61 p.

Macdonald, G.A., 1973, Geological prospects for development of geothermal energy in Hawaii: Pacific Science, v. 27, No. 3, p. 209-219.

McMurtry, G.M., Fan, Pow-foong, and Coplen, T.B., 1977, Chemical and isotopic investigations of groundwater in potential geothermal areas in Hawaii: American Journal of Science, v. 277, p. $438-458$

M\&E Pacific, Inc., 1987, Source use application for the Kapoho water system, Kapoho, Hawaii, Hawaii: Report prepared for the County of Hawaii Department of Water Supply, 51 p.

Novak, E.A., and Evans, S.R., 1991, Preliminary results from two scientific observation holes on the Kilauea east rift zone: Geothermal Resources Council Transactions, v. 15, p. 187-189.

Olson, H.J., and Deymonaz, J.E. 1991, The Hawaiian scientific observation hole program preliminary results and status report: Proceedings of the 13th New Zealand Geothermal Workshop, p. 115-120.

Olson, H.J., and Deymonaz, J.E., 1992, The Hawaiian scientific observation hole (SOH) program summary of activities: Geothermal Resources Council Transactions, v. 16, p. 47-53.

Scholl, M.A., Janik, C.J., Ingebritsen, S.E., Kauahikaua, J.P., and Trusdell, F.A., 1993, Preliminary results from an isotope hydrology study of the Kilauea Volcano area, Hawaii: Geothermal Resources Council Transactions, vol. 17, p. 187-194.

Seyfried, W.E., and Bischoff, J.L., 1979, Low temperature basalt alteration by seawater: An experimental study at $70^{\circ} \mathrm{C}$ and $150^{\circ} \mathrm{C}$ : Geochimica et Cosmochimica Acta, v. 43, p. 19371947.

Stearns, H.T., and Macdonald, G.A., 1946, Geology and groundwater resources of the Island of Hawaii: Hawaii Division of Hydrography Bulletin 9, 363 p.

Swain, L.A., 1973, Chemical quality of ground water in Hawaii, Hawaii Division of Water and Land Development Report R48, 54 p.

State of Hawaii Department of Business and Economic Development (DBED) 1990, Hawaii Geothermal Project: A Proposal to Establish the Hawaii Geothermal Resource Verification and Characterization Program, presented by Roger A. Ulveling, Director, Department of Business and Economic Development, on Behalf of Governor John D. Waihee, March, 1990. 
State of Hawaii Department of Land and Natural Resources Division of Water and Land Development (DLNR), 1964, Summary of drilling log and pumping test for Pulama well 910, Pulama, Puna, Hawaii: Circular C26, Job No. 17-K-9, 15 p.

Swanson, D.A., Duffield, W.A., and Fiske, R.S., 1976, Displacement of the south flank of Kilauea Volcano: the result of forceful intrusions of magma into the rift zones: U.S. Geological Survey Professional Paper 963, 39 p.

Takasaki, K.J., 1994, Occurrence and movement of ground water in Kilauea Volcano and adjacent areas of Mauna Loa Volcano, Island of Hawaii, U.S. Geological Survey Open-File Report, 93-82, 28 p.

Thomas, D.M., Cox, M.E., Erlandson, D., and Kajiwara, L., 1979, Potential geothermal resources in Hawaii: a preliminary regional survey: Hawaii Institute of Geophysics Technical Report HIG 79-4, $103 \mathrm{p}$.

Thomas, D.M., 1984, Geothermal resources assessment in Hawaii Final Report: Hawaii Institute of Geophysics, $114 \mathrm{p}$.

Thomas, D.M., 1987, A geochemical model of the Kilauea east rift zone in Decker, R.W., Wright, T.L., and Stauffer, P.H., eds., Volcanism in Hawaii: U.S. Geological Survey Professional Paper 1350, p. 1507-1525.

Thomas, Richard, Whiting, Dick, Moore, James, and Milner, Duey, 1991, Independent technical investigation of the Puna Geothermal Venture unplanned steam release, June 12 and 13, 1991, Puna, Hawaii: Report prepared for the Honorable Lorraine R. Inouye, Mayor, County of Hawaii and the Honorable William W. Paty, Chairperson, Board of Land and Natural Resources, $35 \mathrm{p}$.

Tilling, R.I., and Jones, B.F., 1991, Composition of waters from the research drill hole at the summit of Kilauea Volcano and of selected thermal and nonthermal groundwaters, Hawaii: U.S. Geological Survey Open-File Report 91-133-A, 27 p.

Walker, G.P.L., 1987, The dike complex of Koolau Volcano, Oahu: internal structure of a Hawaiian rift zone: U.S. Geological Survey Professional Paper 1350, p. 961-993. 


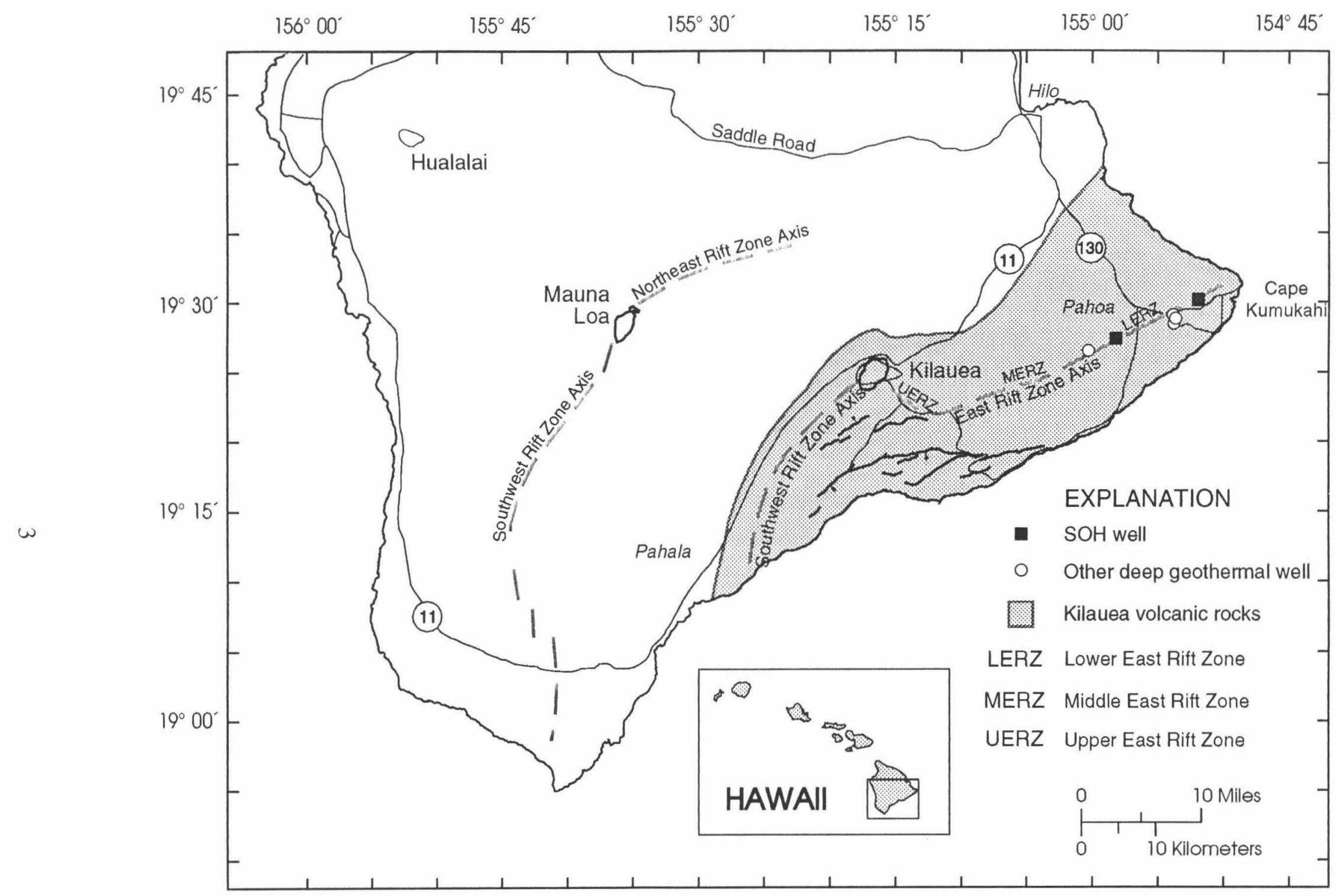

Figure 1. Map of the southern part of the Island of Hawaii showing volcanic rocks of Kilauea Volcano, axes of rift zones of Kilauea and Mauna Loa, and locations of geothermal wells. 


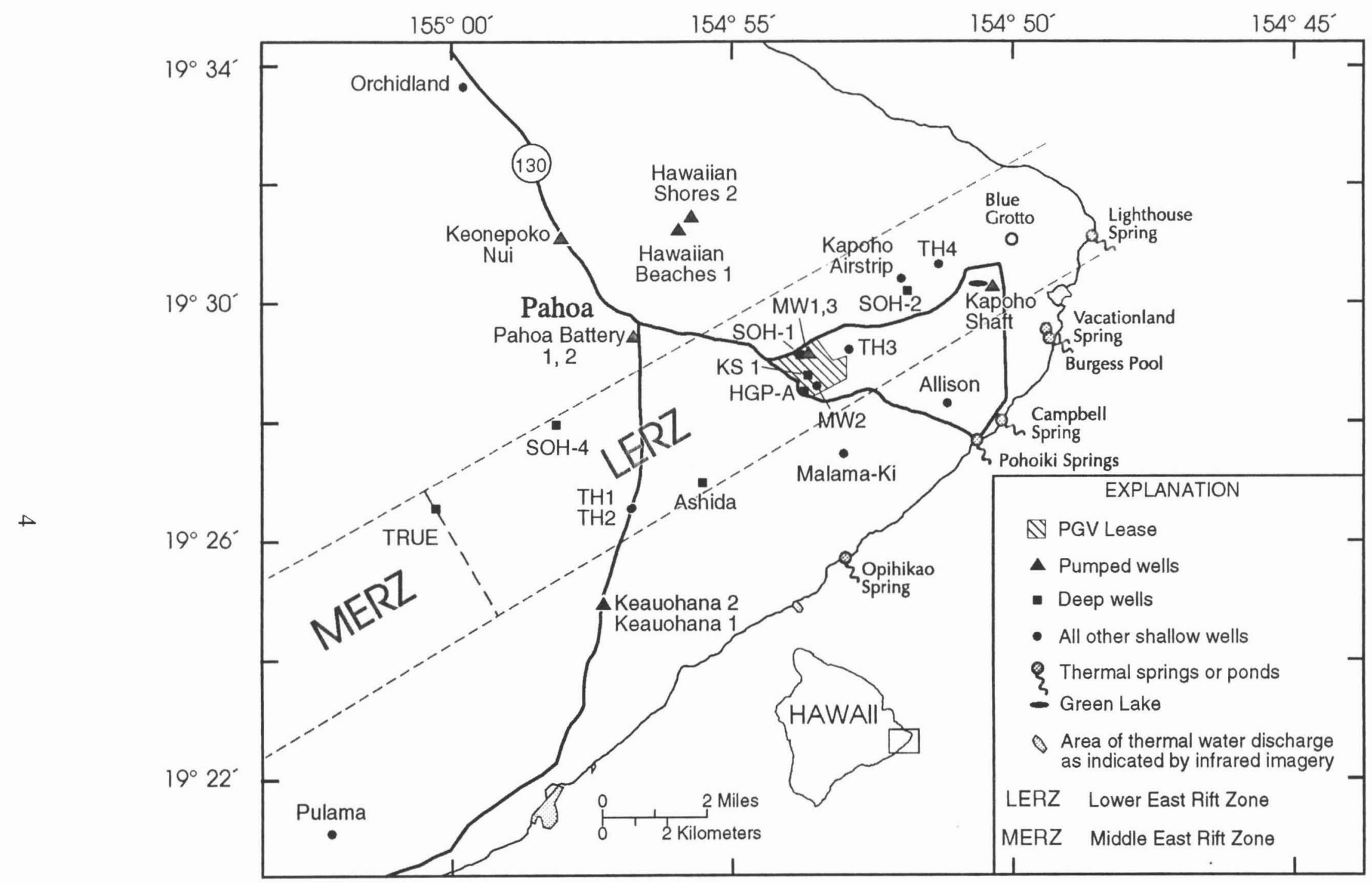

Figure 2A. Wells and springs in the study area within and adjacent to the lower east rift zone of Kilauea. Well data are listed in table 1; wells KS $1 \mathrm{~A}$ and KS 3 (not shown) are located adjacent to KS 1. Also shown is the lease area for the existing $25 \mathrm{MW}$ geothermal development by Puna Geothermal Venture (PGV). 


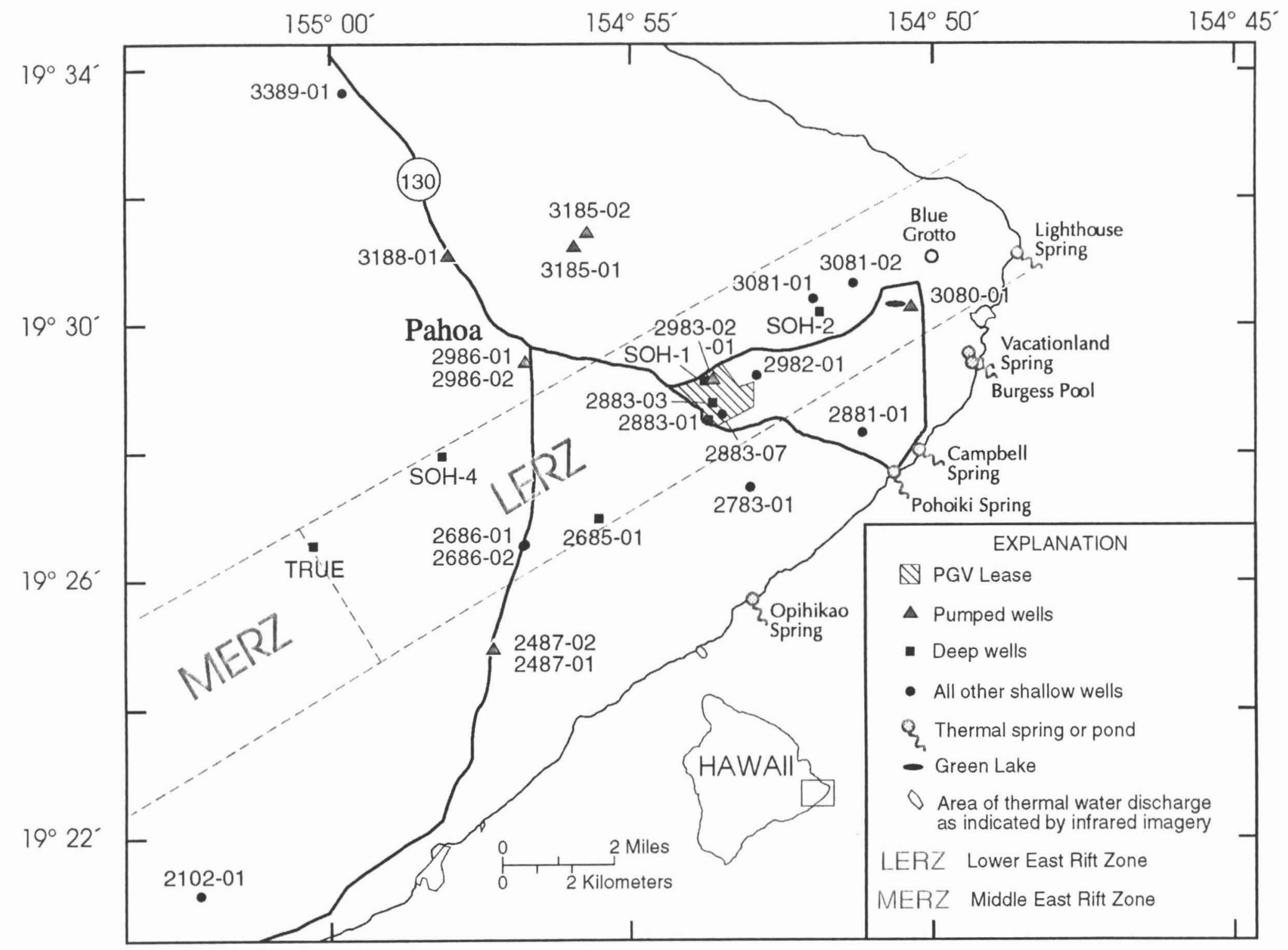

Figure 2B. Wells in the study area identified by state well number. Other features are the same as shown in figure $2 \mathrm{~A}$. 


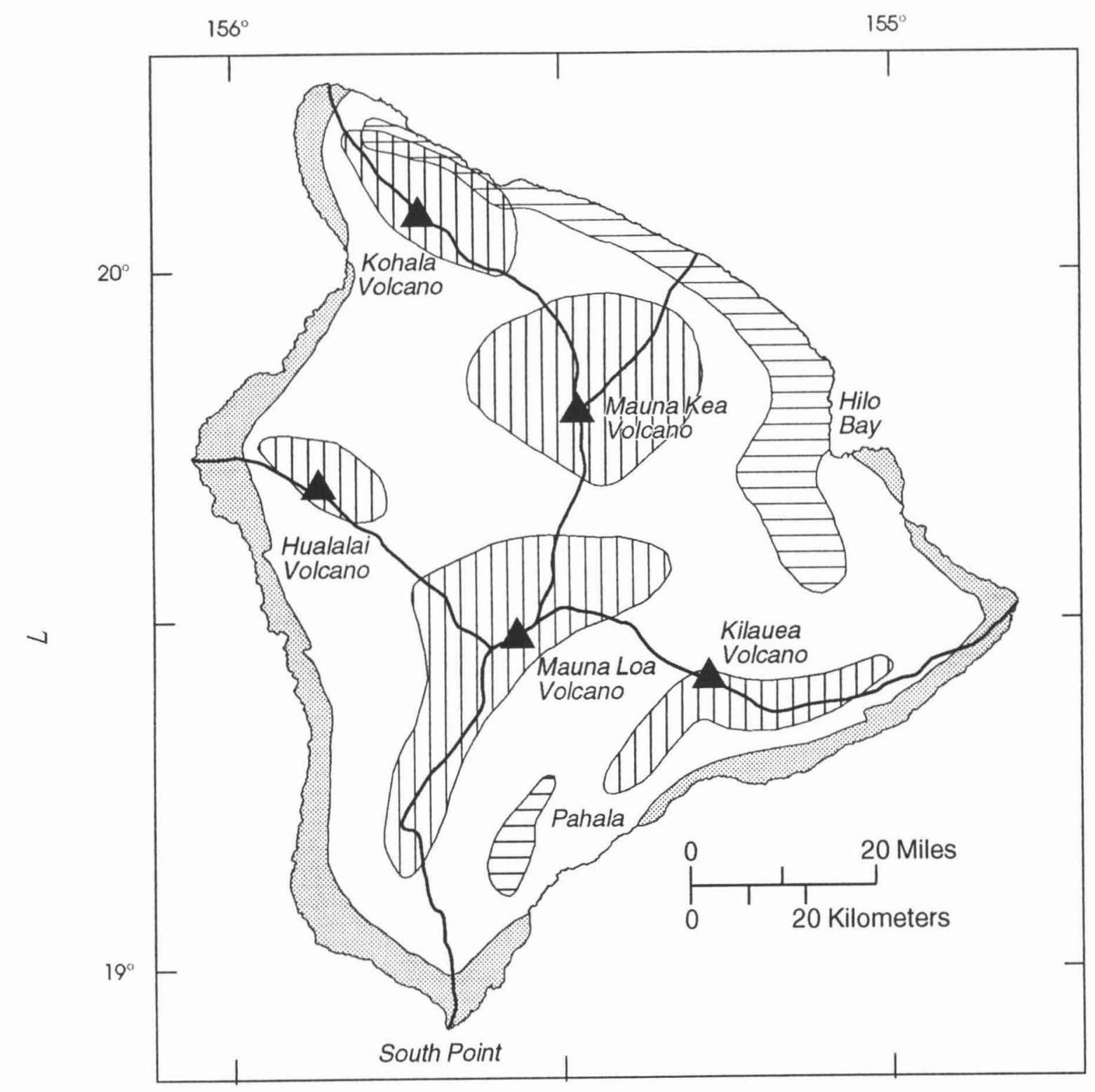

EXPLANATION

Basal ground water floating on saline ground water

Brackish basal ground water in dike-free rocks

Ground water impounded by dikes in rift zones

Ground water perched on soil or ash layers overlying basal ground water

Boundary of major drainage basin

- Volcano

Figure 3. General distribution of different ground-water types and boundaries of major drainage basins on the Island of Hawaii (From Takasaki, 1994). 


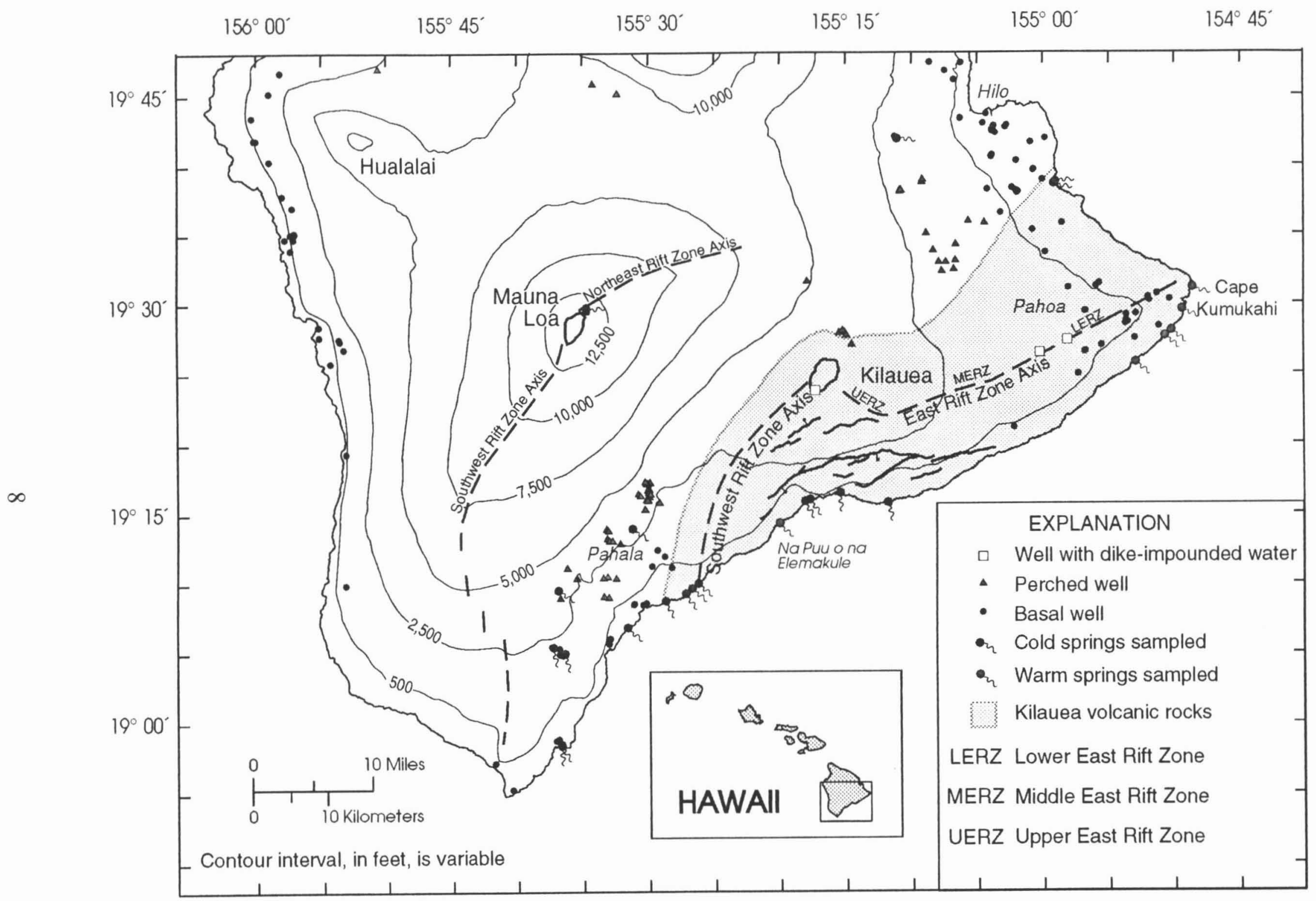

Figure 4. Map of the southern part of the Island of Hawaii showing contours of land-surface elevation, locations of existing wells, and locations of springs sampled by Janik and others (1994). 


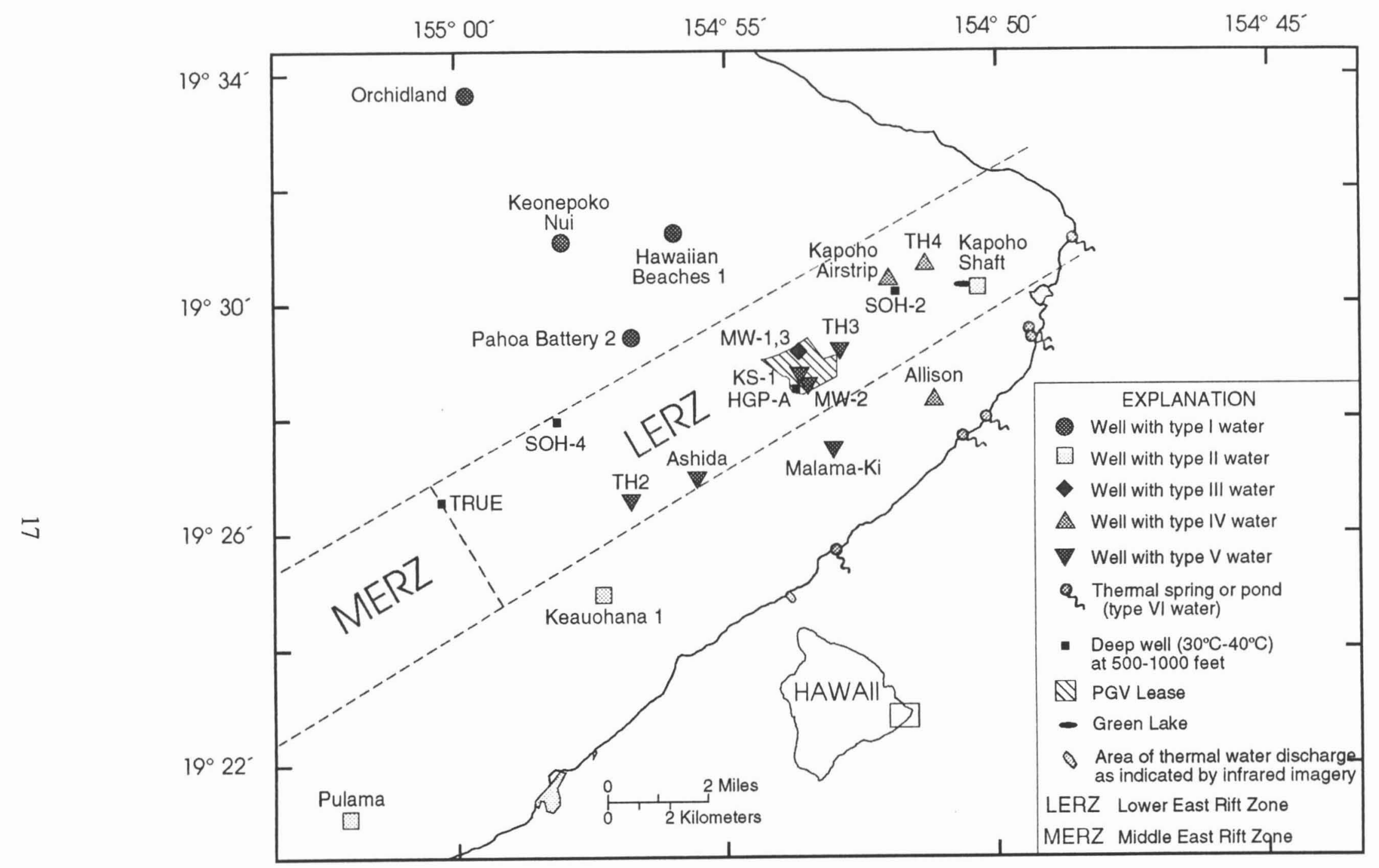

Figure 5. Wells tapping different types of shallow groundwater, distinguished on the basis of temperature and chloride content (see text). Well locations correspond to those shown and named in figure 4. Some deep geothermal wells are shown as encountering Type $\mathrm{V}$ ground water, based on temperatures and water chemistry of fluids encountered in the upper 500-1,000 feet. 


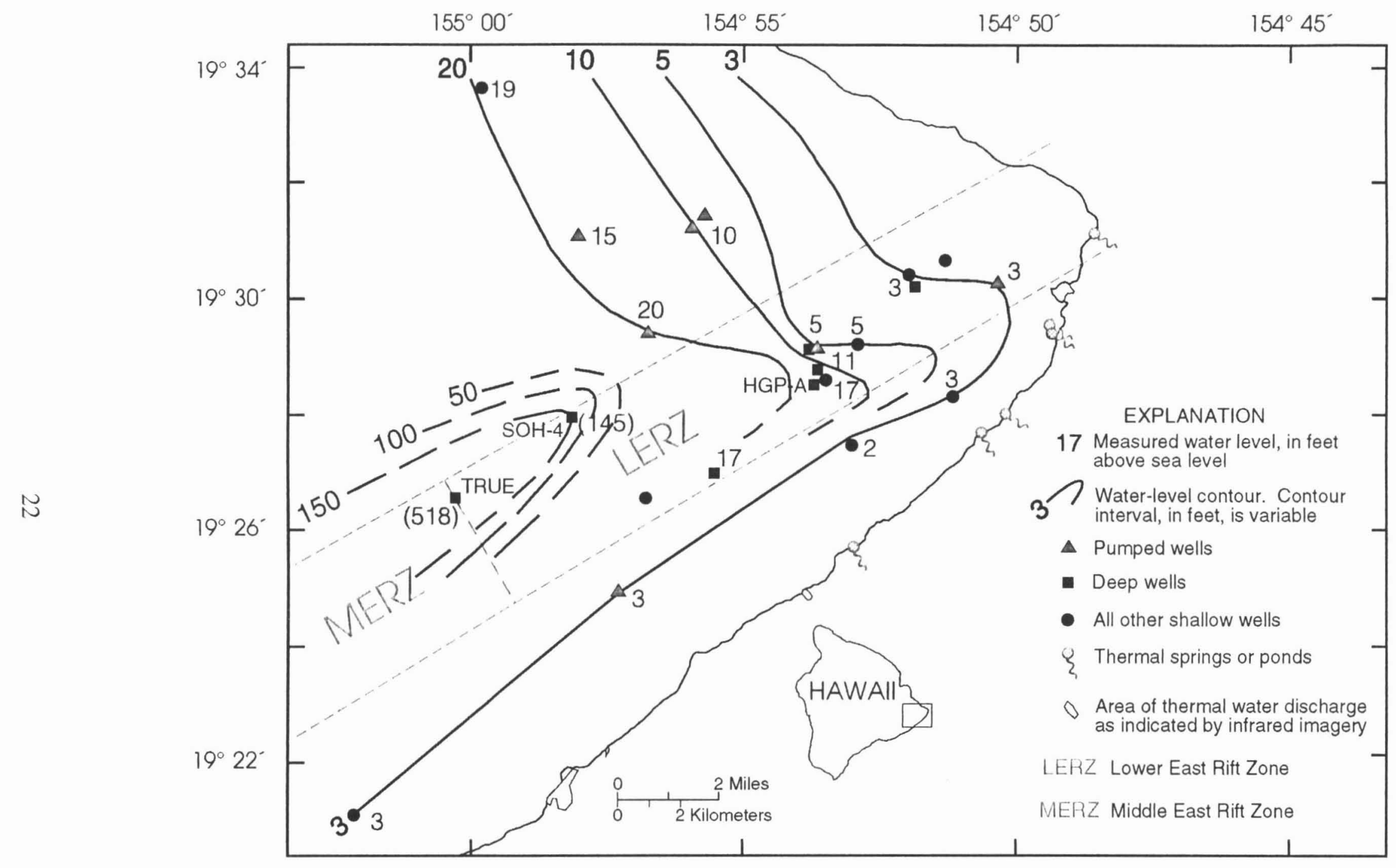

Figure 6. Water-level contours and representative water levels measured in wells tapping basal ground water in the study area. Water-levels shown in parentheses are based on post-completion pressure surveys (True Mid-Pacific well) or measurements made during drilling at depths near 2,300 feet ( $\mathrm{SOH}-4)$. 